\title{
THE IMPORTANCE OF BEING ADEQUATE: DUE PROCESS REQUIREMENTS IN GLASS ACTIONS UNDER FEDERAL RULE 23
}

\section{INTRODUCTION}

When the Federal Rules of Civil Procedure were amended in 1966 , rule 23 was completely rewritten. ${ }^{1}$ Since then class actions have flourished, and most of them have been of the "common question" variety authorized by subdivision (b)(3), in which members of the class are related to one another only because their respective positions with regard to an adverse party ${ }^{2}$ are linked by common questions of law or fact; they are not united by prior legal relationships. ${ }^{3}$ One of the more radical of the 1966 amendments extended the binding effect of class action judgments to absent members of classes in (b)(3) actions, the category which, because of the lack of unity of interests among the members of the class, offers the least protection to absentees. The draftsmen of amended rule 23 , concerned that their expansion of the binding effect of a judgment not deprive absent class members of due process of law, erected procedures designed to give some additional protection to absentees.

${ }^{1}$ FED. R. Crv. P. 23(b) now provides:

Class Actions Maintainable. An action may be maintained as a class action if $\ldots$ :

(1) the prosecution of separate actions by or against individual members of the class would create a risk of

(A) inconsistent or varying adjudications with respect to individual members of the class which would establish incompatible standards of conduct for the party opposing the class; or

(B) adjudications with respect to individual members of the class which would as a practical matter be dispositive of the interests of the other members not parties to the adjudications or substantially impair or impede their ability to protect their interests; or

(2) the party opposing the class has acted or refused to act on grounds generally applicable to the class, thereby making appropriate final injunctive relief or corresponding declaratory relief with respect to the class as a whole; or

(3) the court finds that the questions of law or fact common to the members of the class predominate over any questions affecting only individual members, and that a class action is superior to other available methods for the fair and efficient adjudication of the controversy....

2 Throughout the rest of this Comment, the party adverse to the class will be called "the opposing party." This term seems least likely to cause confusion. The rule itself refers to "the party opposing the class," FED. R. CIV. P. 23(b)(2), but this appellation could connote the narrower meaning of opposition to maintenance of the suit as a class action. Use of the phrase "adverse party" would be confusing in light of this Comment's discussion of adverse interests within the class.

${ }^{3}$ C. Wright, HaNdBook of the LaW of Federal Courts 312 (1970). 
As amended, rule 23 is replete with procedural safeguards that were lacking in the original rule. Subdivision (a) establishes prerequisites to the maintenance of any class action, ${ }^{4}$ and subdivision (c) requires the trial court to make an early determination of whether the class action is to be maintained and to provide for notice to members of the class. ${ }^{5}$ In class actions maintained under subdivision (b)(3), the rule requires that "the best notice practicable under the circumstances" be sent to members of the class; this requirement is an additional safeguard to (b)(3) class members beyond the basic protection afforded by subdivision (a). Unresolved on the face of the rule is the question of how much weight each of its safeguards has in relation to the others. Most troublesome is the question of the relative importance of the mandatory (c)(2) notice requirement in (b)(3) actions and the requirement of subdivision (a)(4) that in all class actions the class representative "fairly and adequately protect the interests of the class."

Analysis of the interaction of the notice and adequate representation requirements usually occurs in cases in which the notice requirement is unfulfilled. Absent class members who have not received notice of the suit seek to avoid the res judicata effect of the judgment, or the opposing party argues that the named party cannot proceed with the suit unless he is able to provide notice to all absent class members. ${ }^{6}$ In each case, the

t FED. R. Civ. P. 23(a) provides:

Prerequisites to a Class Action. One or more members of a class may sue or be sued as representative parties on behalf of all only if (1), the class is so numerous that joinder of all members is impracticable, (2) there are questions of law or fact common to the class, (3) the claims or defenses of the representative parties are typical of the claims or defenses of the class, and (4) the representative parties will fairly and adequately protect the interests of the class.

${ }^{5}$ FED. R. CIV. P. 23(c) provides in part:

(2) In any class action maintained under subdivision (b)(3), the court shall direct to the members of the class the best notice practicable under the circumstances, including individual notice to all members who can be identified through reasonable effort. The notice shall advise each member that (A) the court will exclude him from the class if he so requests by a specified date; (B) the judgment, whether favorable or not, will include all members who do not request exclusion; and (C) any member who does not request exclusion may, if he desires, enter an appearance through his counsel.

(3) The judgment in an action maintained as a class action under subdivision (b)(1) or (b)(2), whether or not favorable to the class, shall include and describe those whom the court finds to be members of the class. The judgment in an action maintained as a class action under subdivision (b)(3), whether or not favorable to the class, shall include and specify or describe those to whom the notice provided in subdivision (c)(2) was directed, and who have not requested exclusion, and whom the court finds to be members of the class.

${ }^{6}$ The most important recent case of the latter variety is Eisen v. Carlisle \& Jacquelin, 417 U.S. 156 (1974) (Eisen III). 
party contending that the judgment is binding on absentees argues that fair and adequate representation, without notice, can fulfill the requirements of due process for a representative suit. ${ }^{7}$

Rarely has the inquiry proceeded in the opposite direction to ask whether notice alone, absent adequate representation, can satisfy the requirements of due process. A recent Tenth Circuit case, In re Four Seasons Securities Laws Litigation, ${ }^{8}$ is one of the few cases in which parties asked a court to hold that notice, by itself, can satisfy due process. ${ }^{9}$ The question presented in Four Seasons was whether an absent class member who had received adequate notice ${ }^{10}$ could obtain relief from the judgment by arguing that its interests had not been fairly and adequately protected by the named plaintiffs, thereby denying due process of law and rendering the judgment void as to the absentee.

The court in Four Seasons denied the absentee relief from judgment, holding that "due process may be satisfied by notice alone and that, where due process is thus satisfied, adequacy of representation need not be shown as a matter of constitutional necessity." 11 The proposition embodied in this holding seems to be wrong, and this Comment will attempt to demonstrate that receipt of notice by absent members of a class in a (b)(3) - "common question"-class action should not preclude those absentees from attacking the judgment, as to them, on the ground of lack of adequate representation required by rule 23(a)(4). Notice may not substitute for adequate representation. The notice requirement in rule 23 is only a component of the requirement of adequate representation; and the purpose of the former is to buttress the latter, helping to ensure that absentees are accorded due process of law. The Four Seasons case presents the issue; ironically, it is an extreme case that warrants an exception to the proposed rule.

\section{A. The Rule}

One of the draftsmen's purposes in amending rule 23 was to rid the rule of its typing of class actions in terms of "the abstract

${ }^{7}$ See, e.g., $2 d$. at 176.

${ }^{8} 502$ F.2d 834 (10th Cir.), cert. denied, 95 S. Ct. 516 (1974).

${ }^{9}$ Other cases holding absentees bound by a judgment after having received notice are collected in note 138 infra, but none of them deals squarely with the interaction of the (a)(4) and (c)(2) requirements.

${ }_{10}$ There was a question in the suit whether the one notice sent had issued pursuant to rule $23(\mathrm{c})(2)$ or $23(\mathrm{e})$, or both, see note 52 infra, but the court held that notice had been adequate.

${ }^{11} 502$ F.2d at 843 . 
nature of the rights involved."12 The "spurious" class action was particularly vexing. The judgment in such an action extended only to the named parties and to parties who intervened, unlike the judgment in a "true" or "hybrid" suit which bound the whole class. ${ }^{13}$ Courts had trouble deciding which label to apply to a particular action, and the spurious action proved to be an "anomaly because, although denominated a 'class' action and pleaded as such, it was supposed not to adjudicate the rights or liabilities of any person not a [named] party."14

The anomaly was more than academic. Because judgments in spurious class actions bound only named parties and intervenors, the rule was little more than a permissive joinder device. It was hard to see how it added anything to rule 20, the permissive joinder provision of the Federal Rules. ${ }^{15}$ Furthermore, some courts broadened the spurious class action rule by allowing intervention after rendition of judgment, a practice tantamount to taking bets after the race has been run. They justified this socalled "one-way intervention" on two grounds: first, any person who could qualify as a member of the class should be entitled to benefit along with the rest of the class; ${ }^{16}$ and second, allowing post-judgment intervention differentiates the class action device from permissive joinder. ${ }^{17}$ Some courts and commentators criticized the spurious class action rule as superfluous ${ }^{18}$ while others

${ }^{12}$ Advisory Committee's Note, 39 F.R.D. 98 (1966). The three categories set out in the original rule were defined as follows: "the so-called 'true' category was defined as involving 'joint, common, or secondary rights'; the 'hybrid' category, as involving 'several' rights related to 'specific property'; the 'spurious' category, as involving 'several' rights affected by a common question and related to common relief." Id.

${ }^{13}$ Id.

${ }^{14}$ Id. 99.

15. The intended advantage of the spurious category was "that it would invite decisions that a member of the 'class' could, like a member of the class in a 'true' or 'hybrid' action, intervene on an ancillary basis without being required to show an independent basis of Federal jurisdiction .... These results were obtained in some instances but not in others." Id.

${ }^{16}$ See, e.g., Kalven \& Rosenfield, The Contemporary Function of the Class Suit, 8 U. CHI. L. Rev. 684, 695-701 (1941): "We have pointed out that the basic function of the class suit is achieved only if the decree is held open to permit the absentee members of the class to come under the decree after the decision and thus obtain the benefits of litigation ...."

${ }^{17}$ Id. 700 . 1956):

${ }^{18}$ See, e.g., Rank v. (Krug) United States, 142 F. Supp. 1, 154-55 n.93 (S.D. Cal.

Either Rule 23 is inconsistent within itself by calling for adequacy of representation and yet permitting a suit thereunder which does not culminate in a binding decree despite satisfaction of due process, or the Rule is consistent and permits as class suits only those in which the decree will bind absent parties virtually present. 
tried to avoid the anomaly by attributing more latitude to the rule than it could reasonably, or equitably, bear. ${ }^{19}$ Neither resolution of the problem was satisfactory.

Amended rule 23 abolished the spurious class action and replaced it with subdivision (b)(3). Judgments in class actions maintained under subdivision (b)(3) bind all members of the class described in the judgment. ${ }^{20}$ Under subdivision (b)(3), " $[t]$ he court is required to find, as a condition of holding that a class action may be maintained . ... that the questions common to the class predominate over the questions affecting individual members." ${ }^{21}$ A (b)(3) action differs from the other kinds of class actions authorized by the rule in two major respects. First, subdivision (c)(2) requires that notice be sent to subdivision (b)(3) absentees; second, subdivision (c)(2) permits a (b)(3) absentee to exclude himself from the class and thereby escape the binding effect of the judgment. Subdivision (b)(3) absentees who fail to exclude themselves within a time prescribed by the court are included in the judgment, as are all absentees in (b)( 1$)$ and (b)(2) class actions. Thus, under the amended rule the scope of the binding effect of the old "spurious" class action is broadened beyond named parties and intervenors, but constricted to preclude post-judgment intervention.

\section{B. The Problem: A Case in Point}

In re Four Seasons Securities Laws Litigation ${ }^{22}$ was a set of actions brought by creditor-stockholders against the former officers, directors, accountants, and investment bankers of various corporations related to Four Seasons Nursing Centers of America, Inc. The actions were consolidated by order of the Judicial Panel on Multidistrict Litigation in the Western District of Oklahoma and were captioned "M.D.L. 55." Prior to these proceedings, many of the same creditors and the State of Ohio had participated in reorganization proceedings to recover loans made to the insolvent corporations. The State of Ohio, an ordinary creditor of the Four Seasons companies, had objected to the

${ }^{19}$ E.g., Kalven \& Rosenfield, supra note 16; Union Carbide \& Carbon Corp. v. Nisley, 300 F.2d 561, 588-89 (10th Cir. 1961). For a selective compilation of conflicting views on the propriety of "one-way intervention," see cases and authorities cited in Advisory Committee's Note, 39 F.R.D. 98, 105 (1966).

${ }^{20}$ A judgment which will "include" all members of the class is not necessarily the same as a judgment which "binds" them all. The former phrase refers only to the scope of the judgment when rendered. A court may not determine the res judicata effect of its own judgment. See text accompanying notes 128-31 infra.

${ }_{21}$ Advisory Committee's Note, 39 F.R.D. 98, 103 (1966).

${ }^{22} 502$ F.2d 834 (10th Cir.), cert. denied, 95 S. Ct. 516 (1974). 
inclusion of creditor-stockholders in the plan of reorganization and filed three suits of its own against Four Seasons.

The trial court designated five actions as class actions and tentatively defined two plaintiff classes. Ohio was a member of one of those classes. No notice was initially sent to any absent member of the proposed classes, however, because all counsel present asked the court to delay final determination of the classes and sending of notice so that the parties could attempt settlement negotiations. Counsel in M.D.L. 55 subsequently presented to the judge a proposed settlement, and the court entered an order preliminarily approving the settlement and directing that notice be sent to members of the two described plaintiff classes.

Although the Office of the Attorney General of Ohio received two copies of the notice, neither those copies nor the notice published in the Wall Street Journal was read by anyone in the Office. Ohio continued to negotiate with the trustee of the defendant corporation to settle Ohio's three appeals contesting the plan of reorganization and its allocation of shares in the reorganized company to credit-stockholders. Ohio assumed it was not included in either of the M.D.L. 55 classes and failed to request exclusion. Counsel for Ohio did not read the whole order of the court until the deadline for opting-out had passed; later Ohio moved for relief from judgment under rule $60(\mathrm{~b})(1)$, $(4)$, and (6). ${ }^{23}$

The district court granted relief from judgment without relying exclusively on any particular one of the rule 60(b) categories. It found that Ohio had made a strong case that the judgment was void under rule 60(b)(4), remarking that the difference between Ohio's claims and those of other class members cast doubt on the adequacy of representation. In addition, the court gave some weight, under rule $60(\mathrm{~b})(6)$, to the course of dealings between counsel for the defendants in Four Seasons (which Ohio termed "lulling"), although it had held earlier in the opinion that the course of dealing did not excuse Ohio's neglect under rule $60(\mathrm{~b})(1)$. The court based its grant of relief on the "totality of the evidence" under the circumstances.

${ }^{23}$ FED. R. Crv. P. 60(b) provides in part:

On motion and upon such terms as are just, the court may relieve a party or his legal representative from a final judgment, order, or proceeding for the following reasons: (1) mistake, inadvertence, surprise, or excusable neglect; . . (4) the judgment is void; ... or (6) any other reason justifying relief from the operation of the judgment. 
The court of appeals reversed, finding that the district court's decision had been based on the erroneous conclusion that Ohio had been denied due process of law. ${ }^{24}$ The court of appeals found no due process violation because Ohio had received sufficient notice. Under its view, fulfillment of the notice requirement of subdivision (c)(2) is a sufficient condition to support a judgment binding absentees. ${ }^{25}$ In context this conclusion makes sense. Ohio had received not only notice of the suit, but also notice of the settlement hearing and of the terms of the proposed settlement, "the very terms of the impending judgment."26 Ohio was "presented with the unique opportunity of judging, retrospectively, whether its interests had been adequately represented at a time when it was capable of excluding itself if not satisfied."27

The unusual factual setting of Four Seasons justifies the decision of the court of appeals; but the holding obscures the real problem, suggested by the case, as it may come up in future litigation. That problem is whether notice of the pendency of a (b)(3)-“common question"-class action, without more, deprives an absentee of his right to fair and adequate representation. ${ }^{28}$

${ }^{24}$ For purposes of this Comment, it suffices to say that the court of appeals believed the lower court opinion to have been based on due process grounds, and based its reversal on due process grounds. It should be noted that the district court's "totality of the evidence" standard could easily have been interpreted by the court of appeals as a decision under (b)(6) of rule 60-the "other reasons" clause-and reversed on that ground. The district court, after canvassing the evidence under rule $60(b)(1)$ and (b)(4), refused to base its decision on either clause, but it used the same evidence to grant relief on the "totality of the circumstances" (i.e., arguably, rule $60(b)(6)$ ). It is well settled, however, that a motion under rule 60(b)(6) should be granted only if the motion is based on "some reason other than those stated in clauses (1)-(5)" and that although rule 60(b)(6) is to be construed liberally, it should only apply to situations "not covered in the preceding five clauses," 7 J. Moore, Federal Practice fl 60.27[1], at 343 (2d ed. 1974); see Klapprott v. United States, 335 U.S. 601, 613-15 (1949) (opinion of Black, J.); United States v. Erdoss, 440 F.2d 1221, 1223 (2d Cir. 1971); Rinieri v. News Syndicate Co., 385 F.2d 818, 822 (2d Cir. 1967). But see In re Four Seasons Securities Laws Litigation, 502 F.2d 834, 841 (10th Cir.), cert. denied, 95 S. Ct. 516 (1974). The court of appeals in Four Seasons found it unnecessary to pinpoint which of the $60(\mathrm{~b})$ clauses was the basis of the decision, and focused instead on the merits of the due process issue.

25502 F.2d at 843.

${ }^{26} I d$.

${ }^{27} \mathrm{Id}$.

${ }^{28} \mathrm{~A}$ distinction could be made between the right to adequate representation as a prerequisite to maintenance of a class action and the right not to be bound by a judgment already rendered in a suit in which representation was inadequate. Under such a distinction, the finding of adequate representation as a prerequisite might be said to preclude a later suit attacking the binding effect of the judgment because of inadequate representation. The distinction is specious, however, because the requirement of adequate representation as a prerequisite is intended to ensure satisfaction of due process requirements so that the judgment can be held binding if attacked later. If an absentee cannot 
The Four Seasons court felt unguided in its decision because "due process requirements under the facts presented here have [not] yet been articulated."29 This Comment proposes to aid in the articulation of those requirements.

\section{The Requirements of Due Process in a Glass Action}

The procedural context of the Four Seasons case was a motion for relief from judgment under rule $60(\mathrm{~b})$. The case involved a direct attack on the original judgment, rather than a collateral attack in a subsequent suit; but because the court of appeals treated the case as having been decided under rule 60 (b)(4) - "the judgment is void"-the case raises the same issues as would a collateral attack. ${ }^{30}$ The party moving for relief did not allege that the trial court lacked jurisdiction over the subject matter or over the parties, so the judgment could be found void only if the court had proceeded "in such an arbitrary or improper manner that its action may be said to constitute a denial of due process." ${ }^{31}$ The nature and requirements of due process for a class action concern us here.

\section{A. Adequate Representation}

Adequate representation by the named party of the interests of absent parties is a requirement of due process in a class suit. The leading case on adequate representation is Hansberry $v$. $L e e,{ }^{32}$ a suit against landowners who had violated the terms of a racially restrictive covenant. The plaintiffs, homeowners seeking to enforce the terms of the covenant, argued that a prior judgment ${ }^{33}$ in favor of other homeowners seeking to enforce the restriction barred the present defendants from challenging the covenant's validity. The Supreme Court of Illinois held the

attack a judgment (either directly or collaterally) on due process grounds, it matters little that he was entitled to adequate representation during the suit. See generally notes 166-73 infra \& accompanying text.

29502 F.2d at 843.

30 Note, Collateral Attack on the Binding Effect of Class Attion Judgments, 87 Harv. L. REv. 589, 598 \& n.55 (1974).

317 J. MOORE, supra note 24, ๆ 60.25[2], at 309; see Bass v. Hoagland, 172 F.2d 205 (5th Cir.), cert. denied, 338 U.S. 816 (1949). But cf. notes 45-46 infra \& accompanying text. The district court granted Ohio relief under rule 60(b)(6)-"any other reason justifying relief"- -the court of appeals treated the decision as having been based on the view that Ohio was denied due process of law. This ground would be cognizable only under rule 60(b)(4). See also note 21 supra.

32311 U.S. 32 (1940).

${ }^{33}$ Burke v. Kleiman, 277 Ill. App. 519, 189 N.E. 372 (1934). 
validity of the covenant to be res judicata, ${ }^{34}$ even though a factual stipulation upon which the first judgment was based turned out to be false. ${ }^{35}$ Since the court considered the original suit to have been a "class" or "representative" suit, it held the defendants, now seeking relief from the covenant, bound by the prior judgment. ${ }^{36}$

The Supreme Court of the United States reversed, enunciating the basic requirements of due process in a class action. The Court ruled that the defendants could not be bound by the prior judgment for two reasons. First, the plaintiffs in the prior litigation could not be considered members of the same class as the defendants in Hansberry. ${ }^{37}$ The former sought to enforce the covenant while the latter wanted to violate it. ${ }^{38}$

It is plain that in such circumstances all those alleged to be bound by the agreement would not constitute a single class in any litigation brought to enforce it. Those who sought to secure its benefits by enforcing it could not be said to be in the same class with or represent those whose interest was in resisting performance ... . ${ }^{39}$

The Supreme Court of Illinois had failed to perceive, or had chosen to disregard, the obvious point that all the homeowners

${ }^{34}$ Lee v. Hansberry, 372 Ill. 369, 24 N.E.2d 37 (1939).

${ }^{35} \mathrm{Id}$. at $372-74,24$ N.E.2d at 38-40. The parties in the original suit, Burke v. Kleiman, 277 Ill. App. 519, 189 N.E. 372 (1934), had stipulated that the condition precedent to the covenant's taking effect had been satisfied. It turned out that the condition had not been met: only fifty-four percent of the homeowners had signed the covenant; ninety-five percent were required for the restrictions to take effect.

${ }^{36}$ The majority's reliance on the stipulation as res judicata went not only to the merits but also to the question whether the court had jurisdiction over the absentees in order to hold them bound. The defendants in Hansberry had argued in the Supreme Court of Illinois that there was no class, because the class of parties to the covenant could only come into being when ninety-five percent of the homeowners had signed. Even if homeowners who sought enforcement could be said to have represented homeowners who wanted to sell, because all made up one class, that class had never come into being. 372 Ill. at 373,24 N.E.2d at 39.

The dissenting judges agreed:

[I]t seems obvious that until those signatures were obtained and the very terms of the agreement itself complied with, there could by no possibility be even the semblance of a class to be represented in a class suit, even if such a suit could be possible under the circumstances....

Id. at 380,24 N.E.2d at 42 . (Shaw \& Murphy, JJ., dissenting).

${ }^{37} 311$ U.S. at 44.

${ }^{38}$ Of course the Supreme Court of Illinois could have said that defendants in Burke had represented defendants in Hansberry, so that they were all members of the same class and had the same interests. But, as the United States Supreme Court noted, the defendants in Burke never purported to represent anyone or have anyone bound by the result of their litigation. Id. at 45 .

${ }^{39} I d$. at 44. 
did not constitute a single class such that any of its "members" could speak for all the others. The United States Supreme Court corrected the mistake and made plain what already should have been so: persons will not be bound by a judgment in a class suit if they are not members of the class.

The Court's second point, dealing with adequacy of representation, is the facet of the decision that has been emphasized in subsequent cases. The Court, relying upon what it described as the "familiar doctrine of the federal courts," held that "members of a class not present as parties to the litigation may be bound by the judgment where they are in fact adequately represented by parties who are present ...."40 Finding an absence of adequate representation, the Court refused to hold the prior judgment binding on the so-called class members who had been absent from the proceedings.

Hansberry is usually cited for its holding on adequate representation, and it is rarely noted that the main basis of the decision was that the homeowners seeking to violate the covenant could not possibly have been considered members of the class of homeowners who had previously sought to enforce it. ${ }^{41}$ A class so defined would have defied reason. The two thrusts of Hansberry go together: persons absent from the prosecution of litigation may be bound by that litigation only "[1] where the interests of those not joined are of the same class as the interests of those who are, and [2] where it is considered that the latter fairly represent the former . . .."42 In most cases the first requirement will be met rather easily but the second will require close scrutiny by the court. In Hansberry the Court found that the first requirement was not met and indicated that, a fortiori, neither was the second.

${ }^{40} I d$. at $42-43$.

41 The language of the opinion and its repeated emphasis of this point support the view that the main basis of the decision was the difference in classes. Phrases such as the following abound in the opinion: " . . provided that the procedure were so devised and applied as to insure that those present are of the same class as those absent ...." Id. at 43.

One commentator both advanced and rejected the argument that the real rationale for the decision in Hansberry was that two distinct classes were involved. He rejected the argument on the grounds that if the existence of two classes was the basis for decision, then: (1) there was no need for the Court to discuss the adequacy of representation; and (2) there would have been no need to discuss the res judicata effects of the first decision, when it is plain that one class could not represent another. Note, Proposed Rule 23: Class Actions Reclassified, 51 VA. L. REv. 629, 637-38 (1965). These two objections are hollow. The Court had to discuss the res judicata issue because it formed the basis of the Illinois court's holding; and its discussion of adequate representation was integrally related to the finding of separate classes.

12311 U.S. at 41 . 
The odd circumstances of Hansberry, that the absentees should never have been included in the class of the priorlitigation plaintiffs, might be thought to make unnecessary, or to relegate to dictum, the Court's discussion of adequate representation. But such a conclusion misses the point. The Court appreciated that both requirements bear upon the power of the court to render judgment; the problem is one of jurisdiction. The defendants in Hansberry stated "want of jurisdiction" as a ground for reversal of the Illinois Supreme Court judgment. ${ }^{43}$ They meant that the earlier litigation could not be res judicata as to them because they had never appeared before the court or been named as parties. A court has jurisdiction over absent members of a class, an exception to traditional principles of jurisdiction, only by virtue of its jurisdiction over the class representative. ${ }^{44}$ If the supposed absentees are not even members of the class, they are not represented by anyone and have not had their day in court. The same can be said of absentees who have not been represented fairly and adequately: if the representation has not been adequate, the absent class members have not had their day in court through the appearance of the named representative, even if the absentees are bona fide class members. ${ }^{45}$ Want of due process flows from lack of ju-

${ }^{43} I d$. at 35 (Argument for Respondents).

t4 See, e.g., Calgaz v. Calhoon, 309 F.2d 248, 254 (5th Cir. 1962).

${ }^{45}$ Hansbery illustrates the extreme situation of absentee interests completely adverse to those of the "representatives." Given this adversity, it was clear that the absentees could not be deemed members of the' representative parties' "class."

Less extreme situations could contain the seeds of adversity within the class which might result in a denial of due process to absentees. Adequate representation, though only one of the prerequisites enumerated in clause (a) of the rule, has come to embrace several of the other requirements of rule 23 , including ones in (b)(3), see note 46 infra, and (a)(3).

Clauses (a)(3) and (a)(4) require, respectively, that "the claims or defenses of the representative parties [be] typical of the claims or defenses of the class" (typicality), and that "the representative parties will fairly and adequately protect the interests of the class" (adequate representation). Situations satisfying (a)(3) will probably also satisfy (a)(4), unless the representative and his counsel prove incompetent in handling the litigation. At the outset, however, it would appear to a trial court that persons with interests typical of the class' would be able to protect the absentees' interests. On the other hand, it would take an extremely altruistic litigant to represent an entire class in costly and time-consuming litigation if their interests differed from his. Thus the typicality requirement is usually part of the requirement of adequate representation. See Rosado v. Wyman, 322 F. Supp. 1173, 1193 (E.D.N.Y.), aff'd on other grounds, 437 F.2d 619 (2d Cir. 1970), aff'd mem., 402 U.S. 991 (1971). Cases in which absentees alleged that the representative's interests were atypical, like Brennan v. Midwestern Life Ins. Co., 450 F.2d 999 (7th Cir. 1971) and Gonzales v. Cassidy, 474 F.2d 67 (5th Cir. 1973), discussed in text accompanying notes $166-73$ infra, make clear that a prime cause of atypicality may be differences, inherent in one's posture as absentee or as party of record, concerning procedural matters during the trial. See note 145 infra.

The (a)(3) and (a)(4) requirements retain their independent significance when the 
risdiction. ${ }^{46}$

Although Hansberry is considered the Court's principal articulation of the proposition that adequate representation is essential to holding a judgment binding on absentees, the case is distinguishable from modern "common question" class actions in substantial ways. The Supreme Court of Illinois discussed the case as though it had been a class action, but the suit was not brought as a class action and could not have come under the original version of rule 23 , as it was brought in a state court. The parties purportedly bound by the original judgment had not received notice of those proceedings ${ }^{47}$ although they probably were aware of them. ${ }^{48}$ Some commentators have argued that the real basis of the Court's decision was this lack of notice, ${ }^{49}$ but the position can hardly be supported. ${ }^{50}$ The Court did not even mention the absence of notice in its consideration of the protection due absentee interests. ${ }^{51}$ Instead, the Hansberry Court emphasized lack of adequate representation as the basis of its decision.

representative's interests are typical of those of the class but adverse to those of a minority segment of the class. This is the Four Seasons-type situation. Such representatives would meet (a)(3) but might not meet (a)(4). In such a case the court should order the creation of subclasses (with different representatives) having common claims against the opposing party but potentially conflicting interests among themselves. A court's failure to divide the class increases the likelihood of later allegations of inadequate representation.

${ }^{16}$ The constitutional requirement of adequate representation was recognized in Hansbeny and, since 1966, has been embodied in the rule. Nowhere is the source of the constitutional requirement identified, except by citing Hansberry. By looking behind the case to the rationale of the decision one can begin to identify due process notions of jurisdiction as the source of the requirement. Adequate representation is probably a requirement of due process in the sense of fundamental fairness as well, $c f$. text accompanying note 31 supra, but it may ultimately stem more specifically from a court's lack of personal jurisdiction over absentees, if and when their interests differ radically from those of the representative. If the interests of class and class representative are adverse, a court's allowing the suit to proceed as a class action may violate the directive in subdivision (b)(3) that common questions predominate over questions affecting individual members.

i7 372 Ill. at 377, 24 N.E.2d at 41 (Shaw \& Murphy, JJ., dissenting); see Keeffe, Levy \& Donovan, Lee Defeats Ben Hur, 33 ConN. L.Q. 327, 339 (1948).

48 One of the defendants in Hansberry was the spouse of one of the plaintiffs in Burke, 372 Ill. at 372,24 N.E.2d at 39.

${ }^{49}$ E.g., Keeffe, Levy \& Donovan, supra note 47, at 338-39. For further discussion of the notice requirement, see text accompanying notes 53-72 infra.

${ }^{50}$ The statements quoted from Hansbrry in the Keeffe article, supra note 47, say nothing about notice; they only say that something must be done in the original suit to ensure protection of absentee interests. This assertion provides no help in answering the question whether either notice or adequate representation alone may satisfy due process requirements for class stits or whether both are required.

${ }^{51}$ Comment, Adequate Representation, Notice and the New Class Action Rule: Effectuating Remedies Protided by the Securities Laws, 116 U. PA. L. Rev. 889, 910 (1968). 
Nevertheless Hansberry provides only oblique guidance for cases under amended rule 23(b)(3) in which notice has been provided..$^{52}$ Absentees who receive notice of proceedings have already been afforded more protection than absentees without notice. The Hansberry policy that due process requires protection of absentees still stands; but it is not clear whether adequate representation is an absolute requirement or whether receipt of notice weakens the Hansberry rule. That case clearly established adequate representation as an element of due process; but the amendment of rule 23 to require notice to (b)(3) absentees makes Hansberry less weighty authority.

\section{B. Notice}

\section{Hansberry and Mullane}

Individual notice to class members identifiable "through reasonable effort" is required by rule 23 only in (b)(3) suits, ${ }^{53}$ cases in which the interests of the absentees may differ substantially from those of the class representative. The Advisory Committee's Note explains that this "mandatory notice pursuant to subdivision (c)(2), together with any discretionary notice which the court may find it advisable to give under subdivision (d)(2), is designed to fulfill requirements of due process to which the class action procedure is of course subject." 54 The Advisory Committee cites, as authority for the due process requirements, Hansberry and Mullane v. Central Hanover Bank E Trust Co., ${ }^{55}$ presumably representing the leading cases on the respective requirements of adequate representation and notice.

Mullane held that "[a]n elementary and fundamental requirement of due process in any proceeding which is to be accorded finality is notice reasonably calculated, under all the circumstances, to apprise interested parties of the pendency of the action and afford them an opportunity to present their objections." 56 With this declaration in mind, the draftsmen of

52 In the Four Seasons litigation Ohio argued that the notice it received was inadequate, but the district court rejected the argument. In its motion for relief from judgment Ohio argued that the court had "telescoped" its sending of notice of the pendency of the suit and its notice of the settlement order. Post-Hearing Reply Brief for the State of Ohio at 20, M.D.L. 55, 59 F.R.D. 667 (W.D. Okla. 1973) (Opinion No. 4).

$5^{3}$ FED. R. CIV, P. 23(c)(2).

st Advisory Committee's Note, 39 F.R.D. 98, 107 (1966).

55339 U.S. 306 (1950).

${ }^{56} I d$. at 314 . The Court in Mullane invalidated a New York banking law that permitted judicial settlement of accounts without providing individual notice to known 
amended rule 23 tried to avoid constitutional problems by requiring that "the best notice practicable under the circumstances" be provided in (b)(3) suits. ${ }^{57}$ The Advisory Committee thought special notice was warranted in (b)(3) actions because of the likelihood that $(b)(3)$ individuals, because of the potential diversity of interests, would rather prosecute their own litigation than be represented as a member of a class. ${ }^{58}$

Many commentators and courts have refused to accept the view that due process requires individual notice to absentees in a class action, insisting that the Advisory Committee itself was wrong if it thought that the Constitution required mandatory individual notice in (b)(3) actions. ${ }^{59}$ Mullane itself does not compel or even imply the conclusion that notice must be provided to individual absentees. One commentator argues persuasively that the Advisory Committee was "clearly misguided" in interpreting Mullane to require individual notice to absent members of a class.

The entire rationale of the opinion rests on notifying some of the interested parties with a minimum of expense and effort; due process was satisfied even though all of the unknown beneficiaries would not receive notice through the mail. The individual interests of the income beneficiaries ... and the principal beneficiaries ... . were identical to those of other beneficiaries of the same type.

... If anything, the discussion of unknown and conjectural beneficiaries seems to support the opposite conclusion-absentees can be bound without any notice if their interests are adequately represented. ${ }^{60}$

beneficiaries of the trusts involved. Notice by publication to unknown or unlocated beneficiaries was approved.

${ }^{57}$ FED. R. CIV. P. 23(c)(2).

${ }^{58}$ Advisory Committee's Note, 39 F.R.D. 98, 104-05 (1966).

59 See, e.g., Dolgow v. Anderson, 43 F.R.D. 472, 497-98 (E.D.N.Y. 1968), rev'd on other grounds, 438 F.2d 825 (2d Cir. 1971) (too much emphasis on providing notice defeats the purpose of the class action device); Northern Natural Gas Co. v. Grounds, 292 F. Supp. 619 (D. Kan. 1968), aff'd on other grounds and remanded, 441 F.2d 704 (10th Cir. 1971), cert. denied, 404 U.S. 951 (1972); 3B J. MOORE, supra note 24, I 23.55, at 1157-58; C. WRIGHT, supra note 3 , at 313 .

${ }^{60}$ Comment, supra note 51 , at 914 (footnotes omitted); Note, Managing the Large Class Action: Eisen v. Carlisle \& Jacquelin, 87 HARv. L. Rev. 426, 434 (1973): "Indeed, the entire thrust of the case was that the amount of notice that would be required must be determined by balancing the interests of the state in bringing any issues to a final settlement and the interests of those involved in the action in receiving notice."

In other words, absent class members seem to be in the same position as unknown or conjectural beneficiaries in the Mullane situation, perhaps because it is not always clear exactly who the members of a given class are. But see Eisen v. Carlisle \& Jacquelin, 417 U.S. 156 (1974). See also notes 64-72 infra \& accompanying text. 
Still, the requirement of notice retains significance in class actions as a means of ensuring adequate representation. According to Hansberry, due process is denied in class suits "only in those cases where it cannot be said that the procedure adopted, fairly insures the protection of the interests of absent parties who are to be bound by it."61 A Comment written shortly after adoption of the 1966 amendments to the Rules argued that

it would seem a safe inference [from Hansberry] . . . that the Court, consistent with due process, might sanction a rule which did not include any notice requirement, as long as it is guaranteed that the interests of the absentees were adequately represented. ${ }^{62}$

The stumbling block of this thesis is the word "guaranteed." No procedural rule can assure that due process will result in every case. The impossibility of guaranteeing adequate representation requires that notice be provided, so that persons wishing to control their own litigation can exclude themselves from the class and persons who want to remain in the class may appear and take part in the suit.

The notice requirement provides an additional safeguard; its purpose is to buttress the requirement of adequate representation. ${ }^{63}$ It is important to note that under this formulation the notice requirement flows not from Mullane, but from the adequate representation requirement of Hansberry and its incorporation in rule $23(\mathrm{a})(4)$.

\section{Eisen}

The recent case of Eisen $v$. Carlisle $\mathcal{E}$ Jacquelin ${ }^{64}$ has been cited as authority for the proposition that notice is more important than adequate representation in class actions under subdivision (b)(3) ${ }^{65}$ In Eisen, the Supreme Court endorsed a decision of the Court of Appeals for the Second Circuit requiring that individual notice be sent to all known and identifiable class members as a prerequisite to the maintenance of a (b)(3) class action. ${ }^{66}$

61311 U.S. at 42.

${ }^{62}$ Comment, supra note 51 , at 911 (emphasis supplied).

${ }^{63}$ See text accompanying notes 100-04 infra.

64417 U.S. 156 (1974).

${ }^{65} \mathrm{Cf}$. In re Four Seasons Securities Laws Litigation, 502 F.2d 834, 843 n.11 (10th Cir.), cert. demied, 95 S. Ct. 516 (1974).

${ }_{66} 417$ U.S. at 177. The Second Circuit had addressed itself in dictum at an earlier stage of the litigation to the question of notice to absentees in (b)(1) and (b)(2) suits, concluding that "notice is required as a matter of due process in all representative actions, and 23(c)(2) merely requires a particularized form of notice in $23(b)(3)$ actions." 
The Second Circuit's decision had been criticized vehemently by courts and commentators prior to the Supreme Court's affirmance. ${ }^{67}$ Besides arguing that adequate representation formed the crux of rule 23's adherence to due process standards, critics cited the text of the rule: it requires "the best notice practicable under the circumstances, including individual notice to all members who can be identified through reasonable effort." 68 The dispute centered around the meaning of this language.

Although Eisen certainly establishes the importance of notice in rule 23's scheme of protection of absentees, it does not say that notice is more important than adequate representation or that notice may substitute for adequate representation. The Court in Eisen addressed itself to the question of notice only because Eisen, the named plaintiff, argued that he need not provide individual notice to all the members of the class because he had assured the court that he would represent them fairly and adequately. The Court rejected his theory, stating:

We think this view has little to commend it. To begin with, Rule 23 speaks to notice as well as to adequacy of representation and requires that both be provided. Moreover, petitioner's argument proves too much, for it quickly leads to the conclusion that no notice at all, pub-

391 F.2d 555, 564-65 (1968) (Eisen II). The court cited Mullane in support of this position. Although the court characterized its pronouncement as a holding, it is difficult to see how it qualifies as such when Eisen was a (b)(3) action. Indeed, the court made this statement in the course of saying that the case was a (b)(3) action regardless of Eisen's attempts to bring the action under (b)(1) or (b)(2) to avoid the mandatory notice requirement of rule 23(c)(2).

${ }^{67}$ See, e.g., Note, supra note 60; Recent Developments, Eisen III: Fluid Recovery, Constructive Notice and Payment of Notice Costs by Defendant in Class Action Rejected, 73 Colum. L. Rev. 1641 (1973); Note, Eisen v. Carlisle \& Jacquelin-Fluid Recovery, Miniheurings and Notice in Class Actions, 54 B.U.L. Rev. 111 (1974). See also Dolgow v. Anderson, 43 F.R.D. 472 (E.D.N.Y. 1968), rev'd on other grounds, 438 F.2d 825 (2d Cir. 1971); Northern Natural Gas Co. v. Grounds, 292 F. Supp. 619 (D. Kan. 1968), aff'd on other grounds and remanded, 441 F.2d 704 (10th Cir. 1971), cert. denied, 404 U.S. 951 (1972).

That the Eisen III decision was an attempt to circumscribe use of the class action device is apparent from the court of appeals' own statements. Believing that the problem of large injuries to society and to the public is a problem for Congress, the court expressed its view that Congress should "create some public body to do justice in the matter of consumers' claims in such fashion as to afford compensation to the injured consumer." 479 F.2d at 1019 .

The Supreme Court could have reached the same result in Eisen III by refusing to allow the suit to proceed, on the ground that the "difficulties likely to be encountered in the management" of the suit, FED. R. Civ. P. 23(b)(3)(D), were too great, considering that Eisen sought to represent $3,750,000$ purchasers of odd lots on the New York Stock Exchange. It is unfortunate that the Court used the notice requirement to achieve its desired result, causing unnecessary confusion of the theoretical issues.

${ }^{68}$ FED. R. CIV. P. 23(c)(2) (emphasis supplied). 
lished or otherwise, would be required in the present case. This cannot be so, for quite apart from what due process may require, the command of Rule 23 is clearly to the contrary. ${ }^{69}$

If the Court emphasized notice and understated adequacy of representation, it was only because the representative plaintiff eagerly assumed the latter burden but tried to avoid the former.

Obviously the holding in Eisen lays to rest, for the time being, the argument that rule 23 does not require individual notice in (b)(3) class actions. ${ }^{70}$ But Eisen does not lead to the conclusion that notice is a sufficient condition for holding a class action judgment binding on absentees. The Eisen Court held that both notice and adequate representation are required. ${ }^{71}$ The Court has not yet decided the question whether provision of notice in a (b)(3) suit abrogates the requirement of adequate representation. ${ }^{72}$

\section{The Relationship Between Adequate Representation and Notice}

The interplay between the two protections of rule 23 may best be summarized as follows: adequate representation, as a remedy, may serve as a substitute for notice, but receipt of notice, as a precautionary measure, may not substitute for adequate representation. Nothing in the rule or the Constitution

69417 U.S. at 176-77. But see text accompanying note 62 supra.

${ }^{70}$ Eisen decided only that a class action could not be maintained without the provision of individual notice to all identifiable absentees. It did not reach the question whether a judgment would be binding on absentees who had not received notice but who had in fact been adequately represented. This distinction does not suffer from the logical flaw previously mentioned, supra note 28 , because a court could find, after judgment, that an absentee had not received notice but had suffered no harm because of the quality of the representation. If notice is an additional safeguard, as this Comment argues, its absence should not matter in a case in which, because of adequate representation, the additional safeguard was unnecessary.

"See text accompanying note 69 supra. Although the Court speaks of the requirements of the rule-a factor noted by the court in Four Seasons to support its holding that the Constitution does not require a showing that the representation has been adequate, 502 F.2d 834, 841 n.11 (10th Cir. 1974)-the Advisory Committee specifically noted that it amended the rule with due process considerations in mind so that judgments in (b)(3) suits could be held binding on absentees. Text accompanying note 54 supra.

${ }^{72}$ The question here is not whether a court may from the outset let notice substitute for adequate representation and permit an action to proceed as a class action knowing that notice but not adequate representation will be provided. The draftsmen of the rule clearly intended that the court be convinced that the class representative would be able to, and would in fact, provide both. The question here is whether a judgment already rendered, probably after lengthy proceedings or settlement negotiations, can be held binding on absentees who admittedly received notice but allege that the representative's handling of the suit was inadequate. 
requires that there be mutuality, or perfect reciprocity, between the two requirements, and it is the thesis of this Comment that receipt of notice cannot nullify the requirement of adequate representation.

The two requirements are somehow related, but they cannot substitute for each other in any sort of mathematical or automatic way. When representation has been adequate, it will not matter in most cases that absentees were not notified of the suit. This clearly is true in actions in which the rule does not require the provision of notice, and it should be true even in (b)(3) actions. ${ }^{73}$ If either requirement is primary, it is that of adequate representation. If the requirements are equally weighty in principle, the purpose served by the notice requirement can be fulfilled by adequate representation, but not vice versa.

\section{Adequate Representation as a Remedy for Lack of Notice}

In deciding whether absentees will be bound by a judgment when they received less than traditional notice or no notice at all, a court should consider the quality of representation by the named party. ${ }^{74}$ "In the degree that there is cohesiveness or unity in the class and the representation is effective, the need for notice to the class will tend toward a minimum." 75 This is why individual notice has not been considered constitutionally necessary ${ }^{76}$ and is not required by the rule in (b)(1) and (b)(2) actions. ${ }^{77}$ In those actions, the requirements of adequate representation has been recognized as sufficient protection to absentees. The requirement is more easily fulfilled by the class representative in cases under (b)(1) and (b)(2) than in (b)(3) cases because the interests of all class members in the former cases will usually be identical. ${ }^{78}$

In actions arising under subdivision (b)(3), it is harder for the representative to protect the interests of every member of the class. It would be wrong to conclude, however, that this difficulty, combined with the requirement of individual notice, ${ }^{79}$ makes adequate representation unimportant in subdivision (b)(3)

${ }^{73}$ See note 70 supra.

${ }^{74}$ Frankel, Some Preliminary Observations Concerning Cinnl Rule 23, 43 F.R.D. 39, 45 (1967).

753 B J. Moore, supra note 24, 1 23.01[12.-2], at 23-35 \& 36.

${ }^{76}$ But see Eisen v. Carlisle \& Jacquelin, 39 I F.2d 555, 564-65 (2d Cir. 1968) (Eisen II).

77 See 7 A C. Wright \& A. Miller, Federal Practice and Procedure $\$ 1786$, at 144 (1972) [hereinafter cited as WRIGHT \& MILLER].

${ }^{78}$ Id.

79 Eisen v. Carlisle \& Jacquelin, 479 F.2d 1005 (2d Cir. 1973) (Eisen III), vacated and remanded, 417 U.S. 156 (1974). See generally text accompanying notes 64-72 supra. 
actions. The provision for notice in $23(\mathrm{c})(2)$ is intended to close the adequacy-of-representation gap that otherwise exists between (b)(1) and (b)(2) actions on the one hand, and (b)(3) actions on the other. Diluting the adequate representation requirement because the notice requirement exists would put the cart before the horse, and, at the same time, would undermine the rule's protective scheme.

2. Notice as a Substitute for Adequate Representation

An allegation of inadequate representation will not necessarily be overcome by the defense that absentees received adequate notice. The policies of Hansberry and Mullane provide some guidance here:

Justice Stone's discussion in Hansberry intertwines fairness or adequacy of representation of the class with other procedural safeguards. It was plausible to suppose that where claimed inadequacy of representation was the nub of a collateral attack on a class judgment, the question whether members had been informed of the action and thereby had a chance to object to the representation would be distinctly relevant. Informal notice might be thought owing to class members as a matter of "common decency" quite apart from any constitutional necessity. But further, at least where the homegeneity or "solidarity" of the class was open to some question, notice could bear directly on a court's authority to render a judgment with full binding effect on the class. ${ }^{80}$

This does not mean that notice by itself can confer authority on a court to render a binding judgment; it only suggests that notice, as one of several "other procedural safeguards," contributes to a court's authority. The draftsmen of the amended version of rule 23 adopted this position, agreeing that notice to absentees increases the likelihood that a judgment will satisfy due process requirements.

The traditional explanation of the importance of notice is inapposite in the context of class actions. Mullane's notice requirement grew out of the Court's recognition that

"[t]he fundamental requisite of due process of law is the opportunity to be heard." . . This right to be heard has

${ }^{80}$ Kaplan, Continuing Work of the Citril Commitlee: 1966 Amendments of the Federal Rules of Citril Procedure (I), 81 HARv. L. REv. 356, 379-80 (1967). 
little reality or worth unless one is informed that the matter is pending and can choose for himself whether to appear or default, acquiesce or contest. ${ }^{81}$

Unlike the defendant who receives notice in the standard suit, the recipient of notice in a class action is often a potential plaintiff; he is not being offered the usual invitation to defend himself against claims of an adverse party. Someone, the class representative, has already chosen to appear; even a (b)(3) absentee can do no more than put in his own appearance, acquiesce in representation by the named party, object to that representation, or exclude himself from the class.

Substantial impediments stand in the way of an absentee's opting out. If he opts out and has claims similar to those of the class, he probably cannot, in a suit of his own, benefit from the class' victory through use of collateral estoppel; this would offend the courts as a form of one-way intervention. ${ }^{82}$ Any absentee not clearly outside the class is strongly constrained to accept representation by the stranger who has chosen to bring suit. These factors aggravate the basic deterrent to opting out, lack of resources to prosecute one's own litigation. Even if an absentee in a (b)(3) action remains in the class, he may not have the time, money, or expertise to do anything but acquiesce in representation by the named party. ${ }^{83}$ His opportunity to be heard is necessarily only an opportunity to be heard through someone else. ${ }^{84}$ Adequate representation remains crucial.

If the theory were that absentees actually choose to be represented by someone else and consent to that representation, perhaps the adequate representation requirement could be overcome by providing notice of the right to request exclusion. This hypothesis is supported by the observation that, when the old "spurious" class action was considered no more than a permissive joinder device, courts did not scrutinize the quality of representation. ${ }^{85}$ Those who joined such an action were deemed

${ }^{81} 339$ U.S. 306,314 (1950) (citation omitted).

${ }^{82}$ See notes 116-18 infra \& accompanying text. 1971).

${ }^{83}$ See generally Ace Heating \& Plumbing Co. v. Crane Co., 453 F.2d 30, 33 (3d Cir.

${ }^{84}$ It may be objected that an absent class member is no worse off than a party in an ordinary suit who is bound even though his attorney has made mistakes in the course of the proceedings. See Link v. Wabash R.R., 370 U.S. 626, 633-34 (1962). "What distinguishes absent class members is the difficulty in showing any agency relationship between them and the named representative." Note, supra note 30, at 594 n.37.

85 3B J. MOORE, supra note 24, 923.07 [1] (citing, inter alia, York v. Guaranty Truşt Co., 143 F.2d 503, 528-29 (2d Cir. 1944), rev'd on other grounds, 326 U.S. 99 (1945)). But 
to have approved the named party's representation of their interests by their affirmative act of joining the suit. An agency relationship could justifiably be inferred. But this cannot be said of today's absentee, even in a (b)(3) action where he has received notice of the action and of his right to opt out. He may fail to exclude himself for a number of reasons, including inertia, ignorance, misunderstanding, and inaccurate assessment of the representative's intentions or ability to protect the interests of the absentees.

\section{a. The Effect of Failing to Request Exclusion}

It is really the opt-out provision in (b)(3) actions, rather than notice per se, that provides any support for binding an absentee by the judgment in a suit in which he was not adequately represented. If courts were to accept the Eisen $I I$ position $^{86}$ that individual notice is constitutionally compelled in $(b)(1)$ and $(b)(2)$ actions, it is highly unlikely that they would consider themselves relieved of the duty to scrutinize the quality of representation in those types of suits. If the judgments in such suits are to be binding on the entire class, receipt of notice could not possibly be thought to do away with the constitutional necessity of adequate representation. Absent members of $(b)(1)$ and $(b)(2)$ classes may now receive discretionary notice of the pendency of the suit; and the court must direct notice to them if the suit is to be dismissed or compromised. ${ }^{87}$ Yet the requirement of adequate representation is not abandoned in suits in which notice has issued pursuant to those subdivisions of rule $23 .^{88}$

It is only because an absentee may opt out of a (b)(3) class upon receipt of notice under (c)(2) that a court like the Four

see Rank v. (Krug) United States, 142 F. Supp. I (S.D. Cal. 1956), in which the court said in dictum that adequate representation is required even in a spurious class action. Otherwise, there would be nothing gained by use of rule 23 that could not be had through rule 20 permissive joinder. Anticipating the 1966 amendment of the rule, the. court reasoned:

Either Rule 23 is inconsistent within itself by calling for adequacy of representation and yet permitting a suit thereunder which does not culminate in a binding decree despite satisfaction of due process, or the Rule is consistent and permits as class suits only those in which the decree will bind absent parties virtually present.

Id. at $154 \mathrm{n} .93$. The court wanted representatives to owe a duty of adequate representation even to absentees who took the affirmative action of intervening under the old rule.

${ }^{86}$ See note 66 supra.

${ }^{87}$ FED. R. Civ. P. 23(d)(2), (e).

${ }^{88}$ Compare Research Corp. v. Asgrow Seed Co., 425 F.2d 1059 (7th Cir. 1970), with Ace Heating \& Plumbing Co. v. Crane Co., 453 F.2d 30 (3d Cir. 1971). 
Seasons court could conclude than an inadequately represented absentee should be bound. He is bound not because he has received notice of the action but because, according to this theory, he has chosen to endorse the representative as his agent and to approve the representation in advance. He must abide whatever kind and quality of representation he gets. The theory is one of waiver or estoppel.

Because the opt-out provision is the peg upon which binding judgments are to hang, it is necessary to determine what effect failure to opt out was intended to have, and why. The draftsmen's reasons for including the provision are relevant. The rule states in no uncertain terms that "the judgment, whether favorable or not, will include all members who do not request exclusion." " 9 The opt-out provision is a means of allowing "individual preference . . . to operate," 90 even when the court has determined that the suit may be maintained as a class action: allowing prospective members to remove themselves from the class honors "the interest of members of the class in individually controlling the prosecution or defense of separate actions." 91 Subdivision (c)(2) grants special rights to (b)(3) class members, "concomitant to the extension of the binding effect of common-question class judgments." 92

The binding effect of a judgment in a (b)(3) suit, however, extends no farther than the judgments in (b)(1) and (b)(2) actions. It seems fair to say that an absentee's failure to request exclusion may show nothing more than that he did not have a strong interest in controlling his own litigation or that it appeared to him at the inception of the suit that his interests were coextensive with those of the representative (assuming that an absentee even knows what each of those interests is, and that he understands the workings of the class action device and the requisites of adequate representation). ${ }^{93}$ It could be that an absentee's acquiescence in representation by the named party proves no more, even barring ignorance, inertia, etc., than that the absentee agreed with the court that the suit has met the

${ }^{89}$ FED. R. Crv. P. 23(c)(2)(B). But of. notes 128-32 infra \& accompanying text.

${ }^{90}$ Kaplan, supra note 80 , at 391.

${ }^{91}$ Id. (quoting FED. R. CIV. P. 23(b)(3)(A)).

${ }^{92} 3 \mathrm{~B} \mathrm{~J}$. MOORE, supra note 24, If 23.45[1], at $705 \mathrm{n} .21$.

${ }^{93}$ This set of circumstances is unlikely, considering that the courts themselves are struggling with the concept. After sending out notice of the antibiotics class action, the Attorney General of North Carolina received, among others, the following letter: "Dear Sir: I received your pamphlet on drugs, which I think will be of great value to me in the future. I am unable to attend your class, however." Miller, Problems of Gitring Notice in Class Actions, 58 F.R.D. 313, 321-22. 
requirements of subdivision (b)(3) of the rule. He may not have given any thought to the requirements of subdivision (a).

The reasons for providing the (b)(3) absentee with notice and an opportunity to exclude himself argue against treating him differently from $(b)(1)$ and (b)(2) absentees. The former decide for themselves whether their positions are such that they want nothing to do with the class, while the latter have already been declared by the rule, as a matter of law, to have the same interests as the representative. ${ }^{94}$ Once the deadline for exclusion in a (b)(3) action passes, the (b)(3) absentee is in the same position as absentees in other types of class actions. The (b)(3) absentee should have no more of an obligation "to monitor that litigation to make certain that his interests are being protected" 95 than the (b)(1) or (b)(2) absentee. To do so would be to transform into a disadvantage or form of punishment what was intended as protection of absentees in the category of class actions most open to abuse. ${ }^{96}$ Unless the theory of the rule is that the chance to opt out shifts from the trial court to the absentees the burden of detecting potentially inadequate representation and of determining that the suit is not appropriate for class action treatment, ${ }^{97}$ absentees with notice who have not opted out should not necessarily be bound.

\section{b. The Role of the Trial Court}

Shifting the burden of evaluating the ability of the representative to protect the interests of the class from the court to the

\footnotetext{
${ }^{94}$ By definition, the class in a (b)(1) or (b)(2) action comprises all those who will share in or be directly affected by the grant or denial of relief [regardless of whether they are technically included in the class]. Subdivision (b)(3), on the other hand, looks to the existence of a group defined by the dependence of the individual members on the determination of common issues; any' relief ultimately granted may vary among the class members.
}

3B J. Moore, supra note 24, If 23.45[1], at 703. "[I]n most (b)(1) cases, the action will automatically be characterized by a predominance of common questions and superiority of class treatment." Id. 707 n.37. See also Van Gemert v. Boeing Co., 259 F. Supp. 125 (S.D.N.Y. 1966).

${ }^{95}$ Gonzales v. Cassidy, 474 F.2d 67, 76 (5th Cir. 1973).

${ }^{96}$ As several courts have noted, the critical problem raising due process concerns in actions under subdivision (b)(3) is not simply notice of the institution of the action, but whether the absent members actually are adequately represented. Effective representation is especially important in Rule 23(b)(3) actions because the class members are only loosely associated by common questions of law or fact, rather than by any pre-existing or continuing legal relationship.

7A WRIGHT \& MILLER, supra note $77, \S 1786$, at 143 , \& cases cited therein.

${ }^{97}$ For instance, the absentees would have to bring to the attention of the trial court that the class should be divided into subclasses. The rule places the duty of making this determination on the court. Cf. note 45 supra. See generally $7 \mathrm{~A}$ WRIGHT \& MILLER, supra note 77 , at $\$ 1790$. 
absentees does violence to one of the central policies of rule 23 . Active court supervision of the class action suit has been cited by many courts and commentators as central to the functioning of the class action device. ${ }^{98}$ One commentator has said of the judge's discretionary powers:

It is clear that this authority is the key to the philosophy behind the new rule. The judge is no longer a passive observer, allowing the initiative of the opposing attorneys to control the course of the litigation; he plays an active role. In a very real sense, he is the guardian of the interests of the absentees. Only through his constant vigilance and sense of fairness will the radically altered Rule 23 achieve its full potential. ${ }^{99}$

The court should not be relieved of its duty to protect absentees by saying that absentees who were not adequately represented should have protected themselves by requesting exclusion. The interests of absentees who remain in the class must still be safeguarded by the court.

3. Summary: Notice as Part of Adequate Representation

Notice should be viewed as a part of, or handmaiden to, adequate representation. The notice requirement reinforces the requirement of adequate representation. ${ }^{100}$ This proposition, central to the argument of this Comment, has been misunderstood or ignored by courts and commentators who insist on the primary and paramount importance of notice. ${ }^{101}$ "Important as notice may be, coupled as it is with traditional notions of fair

${ }^{98}$ See, e.g., Frankel, supra note 74.

99 Comment, supra note $5 \mathrm{l}$, at 898 . The judge "must not only make the initial decision on maintenance of a class action and constantly ensure that the decision was correct [FED. R. CIV. P. 23(c)(1)], and that the absentees' interests are being preserved; he must also approve any final settlement of a case which has been maintained as a class action."

Id. Judge Weinstein of the Southern District of New York has noted that when

the court becomes convinced during the course of litigation that representation is inadequate it should have power to eliminate the representative character of a case on its own motion, because a defendant, preferring the possible res judicata benefits of a class action, might find it against his interest to make the motion. Weinstein, Revision of Procedure: Some Problems in Class Actions, 9 Buffalo L. Rev. 433, 461-62 (1960). It should be noted that Judge Weinstein was talking about New York's class action rule, but the policy considerations are the same for the Federal Rules.

${ }^{100}$ See text accompanying note 63 supra.

101 See, e.g., Maraist \& Sharp, Federal Procedure's Troubled Marriage: Due Process and the Class Action, 49 TExAS L. REv. 1 (1970). "The amended rule provides that in all class actions, regardless of whether actual notice is given, representation must be adequate. Thus the rule goes beyond the requirements of due process, for if actual notice is given, the adequacy of the representation is immaterial." Id. 15-16. 
play in the constitutional sense, it is still only one of the facets of fair and adequate representation." 102

Notice allows absentees to exclude themselves; but if they do not, the court must carry the burden of ensuring that remaining absentees are protected. That some absentees choose to exclude themselves from the class should not prejudice the rights of those who remain. The latter should not be regarded differently, for purposes of determining whether due process has been satisfied, than members of $(b)(1)$ and $(b)(2)$ classes. In those cases no notice is provided to absentees at all, and yet the presence of adequate representation is enough to satisfy the demands of due process. Eisen II would not change this by its suggestion that notice is a constitutional requirement in (b)(1) and (b)(2) actions as well. Recognition of such a constitutional command would strengthen the procedural requirements provided by the rule to ensure adequate representation. ${ }^{103}$

An assumption that the strengthening of one requirement diminishes the importance or necessity of the other requirement is unsound. If notice and adequate representation are viewed as distinct and independent requirements, it does not follow that either could substitute for the other. ${ }^{104}$ If the argument of this Comment is accepted, that notice is part of adequate representation, then strengthening the notice requirement would fortify the requirement of adequate representation as well.

\section{Competing Interests}

The case for not binding absentees if they have received notice but have not been adequately represented has been stated in the preceding section of this Comment. The policy of the rule and the rule's stated purpose of satisfying due process considerations reinforce each other and suggest that such absentees should be relieved of the effect of judgment. Nevertheless, there are competing interests which might lead a court to conclude that such absentees should be bound. An inquiry into the merits

${ }^{102}$ Degnan, Foreword: Adequacy of Representation in Class Actions, 60 CAL. L. REv. 705, 718 (1972).

${ }^{103}$ Rule 23(d) allows the court to order notice to absent members of a class in an action maintained under subdivisions $(b)(1)$ and $(b)(2)$ as a matter of discretion. "Eren if an absolute notice requirement does not apply to all class actions, it should be kept in mind that notice does help the court in assuring that there is adequate representation of the class." 7A WRIGHT \& MILlER, supra note 77, $\$ 1793$, at 205 . Requiring such notice in (b)(1) and (b)(2) actions would serve the same purpose.

${ }^{104}$ It may even follow that neither can substitute for the other, an unusual conclusion from the premise. The premise must be that the requirements are alternative, not independent. 
of binding an absentee could be "guided by the purpose of the rule to prevent one-way intervention, the interests in the finality of judgments, and related case law precedent."105 The Four Seasons court cited these interests in support of its decision that it need not consider the question of adequate representation.

Each of these admittedly legitimate interests warrants consideration, but whether taken separately or cumulatively, they do not outweigh the policy considerations and constitutional requirements that call for relief from judgment. To some extent, they even support the argument for relief from judgment.

\section{A. One-Way Intervention}

The court of appeals in Four Seasons warned of a return to "one-way intervention" and based its decision partly on a desire to avoid that result. The desire is legitimate: one of the reasons for abandoning the spurious class action and designing the (b)(3) action to include absentees who did not opt out was prevention of one-way intervention. That practice allowed a person to claim "the benefits of a favorable judgment to which he was not a named party," even though "he would not have been bound by an unfavorable judgment rendered against named parties who did not adequately represent his interests." 106 The result was a system in which "conjectural" 107 class members could stand by the wayside during a suit, ready to intervene if the "class" representative won, or to bring separate suits on their own if the representative lost. The practice was unfair to the party opposing the class, because it subjected him to the possibility of an unlimited number of lawsuits and denied him the security of a judgment binding all potential litigants of the particular cause of action.

Courts that allowed one-way intervention under the original rule reasoned that disallowing it would reduce the rule to a permissive joinder device. ${ }^{108}$ If being a member of a class meant only that one could intervene in a suit while it was in progress, the courts reasoned, class membership was worthless. Any individual with interests related to a cause of action could intervene under rule 20 anyway. ${ }^{109}$ Instead of seeking to correct the rule the courts labored to invent a procedure they felt was consistent

105 ऽ02 F.2d at 843.

106 Union Carbide \& Carbon Corp. v. Nisley, 300 F.2d 561, 589 (10th Cir. 1961) (allowing one-way intervention).

in: $C f$. note 62 supra.

tux 300 F.2d at 589. See generally text accompanying notes $15-19$ supra.

10: But see note 15 supra. 
with its purpose. What they created turned out to be more inequitable than what they were trying to avoid, and total revision of the rule became necessary.

No one can disparage the revised version of rule 23 as a mere permissive joinder device. It provides for inclusion in the judgment of all members of the described class who have not requested exclusion. The position taken by the Four Seasons court is that allowing post-judgment opting-out, via rule 60(b) relief from judgment or via collateral attack, gives absentees the same advantage as that formerly enjoyed by sideline-sitters who could intervene after the judgment. As one court has put it, "The difference between 'I will intervene if our side has already won' and 'If I find out our side has lost I will collaterally attack the judgment on due process grounds' may not be very great."110 Courts should be wary of artful ways of unfairly exploiting the class action procedure, but apprehension of a return to one-way intervention through use of rule 60 or collateral attack is unwarranted.

First, use of the term "one-way intervention" in the context of direct or collateral attack on a judgment is incorrect. Absentees seeking relief from judgment want out, not in. To some the distinction may be no more apparent or persuasive than that between conditions precedent and subsequent: with one-way intervention, the absentee waits for judgment and then joins the class; with relief from judgment, the absentee takes his chances with the class from the outset (simply by not requesting exclusion) and acts only if his hopes of winning are not fulfilled. The distinction lies in taking action before or after judgment.

But the practices differ. There is little incentive for an absent member of a class that has lost its suit to seek relief from judgment: obtaining relief gives the absentee no more than the right to relitigate. An absentee will seek relief from judgment only if he believes that he has been inadequately represented or that he has claims different from those of the class and its representative. Only in these cases will an absentee have any better

${ }^{110}$ Philadelphia Elec. Co. v. Anaconda Am. Brass Co., 43 F.R.D. 452, 459 (E.D. Pa. 1968) (dictum). It should be noted that this comment was made in the context of urging courts to keep the scope of rule 23 reasonably narrow. The collateral attacks anticipated by Judge Fullam were attacks on judgments purporting to bind absentees who had not received notice, not absentees who complained about the representation. This concern merits more weight than the fear that absentees whose class has lost will raise the issue of inadequate representation. First, inadequate representation is harder to prove. Second, the insecurity of the opposing party is greater when he thinks he is concluding litigation on a cause of action with a large class, only to find later that half the class received no notice and remain free to press their claims against him. 
chances of success on his own than had the losing class representative. ${ }^{111}$ Obtaining relief from judgment only returns the parties to the respective positions they enjoyed before the class action was brought; it does not give the absentee benefits that accrue to a party intervening after a favorable judgment. ${ }^{112}$

Second, relief from judgment is not automatic as was oneway intervention and as is the option to exclude oneself from the class during the suit. An absent party dissatisfied with the judgment ${ }^{113}$ cannot simply elect to be excluded from the class after judgment as it could have done prior to the deadline for opting out. The party moving for relief from judgment, or defending against a claim of res judicata in a subsequent suit, must prove that he was denied due process of law. ${ }^{114}$ The standard of proof is high: "The [reviewing] court, of course, presumes that the first action was conducted in accordance with due process standards. The burden is upon the party asserting a contrary position to raise the issue and to prove otherwise."115 An absent party cannot be relieved of a judgment solely because there was error in the original suit; the remedy for error is appeal, not motion for relief from judgment.

An absentee, after having requested exclusion, may not benefit from a favorable judgment by arguing that the representation turned out to be unexpectedly good. This would be a true return to one-way intervention. Neither can an absentee who has excluded himself "invoke a judgment in favor of the class as collateral estoppel in a jurisdiction that does not require mutuality as a condition on the application of collateral estoppel."116 Rule 23 does not say whether such a practice would be permissible, but it seems clear that the purpose of amending the rule to

111 Of course the absentee might think he could do better than the class for reasons unrelated to the merits of the case, such as choice of court or ability of counsel. But without a meritorious claim differentiating him from the rest of the class, such an absentee could not obtain relief from judgment. See text accompanying notes $113-15$ infra.

112 This may not be true when the class is composed of defendants, but defendant classes are unusual; and most of this discussion assumes the more common class of plaintiffs.

${ }^{113}$ Dissatisfaction with the judgment is not confined to situations in which the class has "lost." In the Four Seasons case, for example, the plaintiff class that included Ohio negotiated a settlement agreement netting the class several million dollars. Ohio was unsatisfied, however, with its share of the pie.

$114 \mathrm{Or}$, in a motion for relief from judgment under a clause of rule 60 other than (b)(4), the movant must prove whatever is required by that clause.

11. Research Corp. v. Edward J. Funk \& Sons Co., 15 F.R. Serv. 2d 580, 582 n.2 (N.D. Ind. 1971).

116 7A Wright \& Miller, supra note 77, § 1789, at 183; see Sarasota Oil Co. v. Greyhound Leasing \& Financial Corp., 483 F.2d 450, 452 (10th Cir. 1973); Kaplan, supra note 80 , at 391 n.136. 
preclude one-way intervention would prohibit such a practice. ${ }^{117}$ There is little practical difference between intervening postjudgment to benefit from a favorable judgment and bringing suit on one's own, armed with the favorable judgment as collateral estoppel. Allowing an excluded absentee to use the judgment would "make a mockery of the notice and opting-out procedure in Rule 23(c)(2)," 118 but permitting relief from judgment does not so offend the rule. ${ }^{119}$

Finally, another procedure, which resembles one-way intervention more closely than relief from judgment, has been permitted. In Schrader v. Selective Service System ${ }^{120}$ the defendant argued that an absent member of the plaintiff class could not share in the judgment favorable to the class because he had not received the required notice of the suit. The argument was weak and the court rejected it:

A judgment in favor of the defendant against the class may not be binding upon members of the class who later sue the defendant and argue that they were not adequately represented in the class action. But the rationale for this view is that every man must be guaranteed his day in court. This rationale has no application to the converse situation in which defendants have had the opportunity fully to litigate the issues in a previous case. ${ }^{121}$

The defendant should have argued, and perhaps meant to argue, that although allowing this unnotified member of the plaintiff class to benefit from the class judgment might not cause any harm, its implications were dangerous. It amounted to a resurrection of one-way intervention. A putative member of the plaintiff class could demand relief if the judgment were favorable, but could bring his own suit following an unfavorable judg-

117 7A WRIGHT \& MILLER, supra note 77 , § 1789 , at 183.

${ }^{118}$ Id. at 183-84.

119 In fact, the inability of an excluded absentee to use a judgment favorable to the class as collateral estoppel may' accentuate the need for sensible use of the equitable remedy of relief from judgment. An absentee deciding whether to opt out knows that he cannot use collateral estoppel if the class wins. Yet he may be unable to prove the necessary elements of his claim on his own. He may not know whether his interests coincide with those of the representative, but he cannot afford to opt out and go it on his own. Not only is he barred from using the class' favorable judgment, but the opposing party probably could use an unfavorable judgment in defense to the absentee's claims, if it turned out that the absentee's claims were like those of the class. Such a practice would not constitute a form of one-way intervention.

120329 F. Supp. 966 (W.D. Wis. 1971).

121 Id. at 967. 
ment, avoiding the binding effect of the earlier judgment by showing that he never received the required individual notice. ${ }^{122}$ Yet the Schrader court failed even to mention the specter of one-way intervention. In contrast, allowing relief from judgment on due process grounds presents little threat to the integrity or equity of rule 23 .

The court in Schrader probably rejected the defendant's argument against inclusion of absentees because it sounded specious and contrived. The notice requirement was meant to safeguard the rights of absentees, not to reduce a defendant's liability. The objection to letting a defendant argue against inclusion of absentees, ${ }^{123}$ like the objection to one-way intervention, is based on the theory, akin to that of unjust enrichment, that each of these practices gives the party two "days in court." The defendant in such a situation has probably already argued against maintenance of the suit as a class action and lost, just as the one-way intervenor has already been apprised of the terms of the judgment.

In a 60(b)(4) motion, on the other hand, an absentee can be relieved of the effect of the judgment if and only if he proves lack of due process. Even a named party to an individual suit, who has been present in court, will be granted relief if he has been denied due process. There is no more reason to bind an absent class member who has been denied due process than to bind a party in an ordinary action who has in fact had his day in court but has been denied due process. The same principles respecting the integrity and finality of judgments should apply.

\section{B. Finality of Judgments}

Finality of judgments is an important principle in American jurisprudence. The deference accorded to final judgments emerges from the clash of two respected principles: that litiga-

${ }^{122}$ This is another reason for holding that lack of notice should not void a judgment if the representation of the class has been adequate. In this hypothetical case, the benefit of so holding would inure to the opposing party and would protect him against all future litigation of the issue by new plaintiffs whose claims did not differ from those of the class. Cf. note 110 supra.

${ }^{123}$ But see School District v. Harper \& Row Publishers, Inc., 267 F. Supp. 1001, 1005 (E.D. Pa. 1967), where the court objected to the inclusion of all absent members of a described class, not because of considerations of due process to absentees, but because of the potential unfairness to defendants who would be liable to many described plaintiffs against whom they had had no discovery, cross-examination, etc. This concern may be moot if the holding in Brennan v. Midwestern United Life Ins. Co., 450 F.2d 999 (7th Cir. 1971), cert. denied, 405 U.S. 921 (1972), is followed. See text accompanying notes 140-42 infra. 
tion must terminate within a reasonable period of time and that both parties must be treated justly. The principle of res judicata attempts to honor the former interest, while the latter is served by recognizing that "res judicata is not an inexorable command." 124 Certain attacks on a judgment, as by motion for a new trial, appeal, or collateral attack, are accepted means of challenging an otherwise "final" judgment. ${ }^{125}$ The finality principle must be recognized as a concept representing the reconciliation of competing interests, rather than as an absolute command.

Finality of judgments is especially important in the class action context. The opposing party should be protected once and for all from the multiple claims of the class members. The class action, particularly under subdivision (b)(3), should "achieve economies of time, effort, and expense, and promote uniformity of decision as to persons similarly situated," ${ }^{126}$ goals equally beneficial to the class and to the opposing party. Finality also encourages settlement of class actions. A commentator has observed that

too liberal application of collateral review of class actions would discourage settlement of such actions -considered particularly important in complex, multiparty litigation ....-since defendants will be loathe to offer substantial sums in compromise unless they can rely upon the judgment to bind all the class members they and the court expect it to bind. ${ }^{\mathbf{1 2 7}}$

Finality of judgments is a more serious consideration than oneway intervention. The latter permits a class member to share in the recovery when he would not have been bound by an unfavorable judgment; the former, however, prevents an absentee from taking action after judgment that he clearly could have taken before the deadline for opting out.

Yet it is clear that a judgment is res judicata only if it has been rendered in accordance with due process. The Advisory Committee noted this premise in its comment qualifying the bold assertion that "one-way intervention is excluded; . . . [and] the judgment, whether or not favorable, will include the class ...."128 The intent of the Committee is plain: no one is to

${ }^{124} 6 \mathrm{~A}$ J. MOORE, supra note 24, I 60.02 , at 4022 .

${ }^{125} I d$.

${ }^{126}$ Advisory Committee's Note, 39 F.R.D. 98, 102-03 (1966).

127 Note, supra note 30 , at 601 .

${ }^{128}$ Advisory Committee's Note, 39 F.R.D. 98, 106 (1966). 
be let in or out after judgment has been rendered. But there is a caveat:

Although thus declaring that the judgment in a class action includes the class, as defined, subdivision (c)(3) does not disturb the recognized principle that the court conducting the action cannot predetermine the res judicata effect of the judgment; this can be tested only in a subsequent action. ${ }^{129}$

Commentators have reiterated and emphasized this necessary restriction on the otherwise broad scope of class action judgments. ${ }^{130}$ Absent parties "have a clear right in some later litigation to attack the judgment which purports to bind them,"131 and the quality of representation in the original suit has been cited as the most important factor to be considered by a reviewing court. ${ }^{132}$

Attacking a judgment on the ground of inadequate representation presents little threat to the finality of judgments. Judgments obtained in violation of due process of law are void, and " $[\mathrm{b}] \mathrm{y}$ their nature void judgments have no legal binding effect." ${ }^{133}$ Unlike the other clauses of rule 60, (b)(4) applies only to void judgments, which "may be collaterally attacked, i.e., [their] nullity and ineffectiveness asserted at any time, in any proceeding where the validity of the judgment comes in issue and is appropriately challenged." ${ }^{34}$ Attacking such a judgment by a rule 60 (b) motion for relief from judgment presents a lesser threat to the stability of judgments than would a collateral attack on the judgment. A direct attack via 60(b)(4) is heard "within a reasonable time" of the original judgment, in the same court, and probably by the same judge who heard the original action. ${ }^{135}$ As a general proposition, "[d]irect attacks on judgments are greatly to be preferred to collateral attacks."136

Motions under rule $60(\mathrm{~b})$ may pose a threat to the finality of judgments, but no more than any of the other recognized inroads upon the principle of res judicata. The basic integrity of the principle remains intact. If rule $60(\mathrm{~b})$ "has struck a fair

${ }^{129} I d$.

${ }^{130}$ Frankel, supra note 74 , at 46 ; C. WRIGHT, supra note 3, at 314; Kaplan, supra note 80, at 393; 7A WRIGHT \& MILlER, supra note 77, § 1789, at 176.

${ }^{131}$ Frankel, supra note 74 , at 46.

132 Id.

$1337 \mathrm{~J}$. Moore, supra note $24, \mathbb{I} 60.41[1]$, at 801 .

${ }^{134}$ Id. 802.

${ }^{135}$ Note, supra note 30 , at 598 n.55.

${ }^{136}$ Weinstein, supra note 99 , at 460 . 
balance"137 in general, there is no reason it may not be applied to class actions.

\section{Case Law Precedent}

The precedent in this area of class action law is muddled. Cases can be, and frequently are, cited for conflicting positions, each sufficient to decide a particular case but none meeting head-on the question whether notice can substitute for adequate representation. The Four Seasons court, for example, relied on several cases to show that its decision was "not the first time that a class member with notice has been bound by a judgment after failing to take some affirmative action." ${ }^{38}$ Although technically correct, this declaration sheds no light on the problem under consideration, since contradictory statements supporting either side of the issue appear in the cases. ${ }^{\mathbf{1 3 9}}$

$1377 \mathrm{~J}$. Moore, supra note 24, I 60.42 , at 902.

138502 F.2d at 844 . The court cited Brennan v. Midwestern United Life Ins. Co., 450 F.2d 999 (7th Cir. 1971), cert. denied, 405 U.S. 921 (1972); Research Corp. v. Asgrow Seed Co., 425 F.2d 1059 (7th Cir. 1970); Supermarkets General Corp. v. Grinnell Corp., 59 F.R.D. 512 (S.D.N.Y. 1973), aff'd, 490 F.2d 1183 (2d Cir. 1974); Mungin v. Florida East Coast Ry., 318 F. Supp. 720 (M.D. Fla.), aff'd, 441 F.2d 728 (5th Cir. 1970), cert. denied, 404 U.S. 897 (1971); School District v. Harper \& Row Publishers, Inc., 267 F. Supp. 1001 (E.D. Pa. 1967).

Of these cases, only Brennan and Research Corp. are relevant. Mungin is inapplicable to the Four Seasons situation, having involved no charges of inadequate representation. It involved denial of relief under $60(\mathrm{~b})(2)$ and (b)(6), primarily because an unreasonable period of time had passed before the motions were made, and the morants had allowed "intervening events to occur pursuant to the judgment which radically alter[ed] the positions of the parties...." The movants, dissatisfied with settlement terms, had already cashed the checks awarded to them from the settlement fund, and the court treated this as ratification of the settlement. Yet the court remarked that an "offer to restore the entire status quo ante [would] meet the terms which the Court is of the opinion would be just for relief." $318 \mathrm{~F}$. Supp. at 735 . This illustrates how liberally a court may be willing to construe rule 60 (b). Cf. text accompanying note 137 supra.

The movants in Supermarkets General made no allegations of inadequate representation, and the closest they came to alleging a want of due process or noncompliance with rule 23 was the argument, as an alternative to their primary reliance on excusable neglect, that the notice provided was insufficient because it went to the wrong person.

In Harper $\&$ Row, the court would not even allow the suit to proceed as a class action. The court's language that may have influenced the Four Seasons court was that where a class member "simply ignores the notice, whether by intention or by inadvertance, it becomes, by inaction alone, a member of the class to be bound by the judgment." $267 \mathrm{~F}$. Supp. at 1005, quoted in Brief for Appellant Jack L. Clark at 30, In re Four Seasons Securities Laws Litigation, 502 F.2d 834 (10th Cir. 1974). Far from approving of this result, the court protested against "[s] uch a radical extension by [sic] this Court's jurisdiction by the mere inaction of a non-appearing, non-resident citizen" which would be, in the court's view, "unprecedented," 267 F. Supp. at 1005.

${ }^{139}$ Ohio asserted: "No case has held that notice to absent members of a class is sufficient to satisfy due process." Brief for Appellee at 43 , In re Four Seasons Securities Laws Litigation, 502 F.2d 834 (10th Cir. 1974). The Four Seasons defendants claimed that the "wealth of judicial authority ... and the absence of a single judicial decision to the 
Although the cases provide no clear answers, they do lend some insight into the criteria and policy considerations relevant to a resolution of the notice/adequate representation controversy. Far from supporting the view that receipt of notice is sufficient to bind absentees, the relevant cases, on close analysis, indicate that adequate representation must also be found.

\section{Requirement of Adequate Representation Implied}

In Brennan v. Midwestern United Life Insurance Co., ${ }^{140}$ the Court of Appeals for the Seventh Circuit implied that a judgment would be void as to notified absentees if they had not been adequately represented. The movants in Brennan alleged inadequate representation as an alternative to their primary allegation in support of a motion for relief from judgment under rules $60(\mathrm{~b})(4)$ and $(\mathrm{b})(6)$. The plaintiff class of which movants were members had won a securities fraud suit maintained under subdivision (b)(3), but movants were denied a share of the recovery because they failed to respond to interrogatories directed both to absent members of the class and to the class representatives. The claims of the absentees were dismissed with prejudice, as the notice provided pursuant to rule 23(c)(2) had warned. ${ }^{141}$ The reviewing court held that "absent members of a class who receive notice of the pendency of the class suit may be subjected to the party discovery procedures permitted under the Federal Rules." 142 Absentees were required to take some affirmative action to benefit from the judgment.

contrary demonstrates that the court below applied the wrong legal standard" in considering Ohio's motion for relief from judgment. Brief for Appellant Jack L. Clark at 30, In $r e$ Four Seasons Securities Laws Litigation, 502 F.2d 834 (10th Cir. 1974).

Both statements are technically accurate, because there has been no other case in which a court has found a combination of inadequate representation and adequate notice. No case has yet had to decide that notice was sufficient to satisfy due process. Even the Supreme Court in Mullane only said that notice was "an elementary and fundamental requirement of due process," 339 U.S. at 314 (emphasis supplied). No case in which absentees received notice has found absentees denied due process, because there have always been other factors supporting the receipt of notice to allow the court to deem the judgments binding. The statement of the Four Seasons defendants in support of their assertion, that "those decisions which have refused to bind absent class members to the judgment entered for or against the class have uniformly involved class members who received no notice of the action," Brief for Appellant Jack L. Clark at 30, In re Four Seasons Securities Laws Litigation, 502 F.2d 834 (10th Cir. 1974), is misleading. The absence of notice was rarely cited by the court rendering the decision as the reason for denying binding effect. Hansberry is a good example. See text accompanying note $\mathbf{4 7}$ supra.

${ }^{140} 450$ F.2d 999 (7th Cir. 1971), cert. denied, 405 U.S. 921 (1972).

${ }^{141}$ Id. at 1001-02.

${ }^{142}$ Id. at 1006. 
The movants raised the issue of adequate representation to buttress their contention that they, as absentees, should not have been required to respond to discovery orders. They argued in the alternative that if such procedures were proper, the sanction for failing to respond should have been only exclusion from the class, not extinction of their claims against the defendant without their sharing in the relief obtained by the class.

The allegation of inadequate representation was that counsel for the class representatives should have opposed the discovery orders or taken an appeal. The court disagreed:

Since we have considered movants' arguments on their merits ... and have concluded that the discovery procedures were proper, this argument loses much of its strength. But even if it could be said that counsel should have opposed the requested discovery, that does not imply that movants were inadequately represented. Adequate representation does not demand absence of error in judgment. ${ }^{143}$

The court based its decision not on the fact that movants had received "full notice of the proceedings," 144 but rather on a finding that the representative's conduct of the action had been adequate. ${ }^{145}$ Another factor militated against granting relief: two

143 Id.

144 Id. The defendants in Four Seasons cited the following passage from the Brennan opinion in support of their position:

Members of a class, having had full notice of the proceedings and the opportunity to seek the advice of a lawyer of their own choosing and not having availed themselves of that opportunity, may not ignore the advice of qualified counsel for the class and later complain about the advice given.

Reply Brief for Appellant Jack L. Clark at 10-11, In re Four Seasons Securities Laws Litigation, 502 F.2d 834 (10th Cir. 1974). But this statement must be taken in context: the court in Brennan found the representation adequate. See note 145 infra \& accompanying text. In Brennan counsel for the class had advised the absentees to respond to the discovery orders; the court characterized this advice as potentially erroneous when given but ultimately sound, and in any case not so derelict as to constitute inadequate representation of the absentees.

145 "At the time the suit was designated a class action, the district court determined that the class members would be represented adequately by the named plaintiff and her counsel. The successful prosecution of the action serves to confirm that determination." $450 \mathrm{~F} .2 \mathrm{~d}$ at 1006 . The representative plaintiffs prosecuted their action successfully in Four Seasons, too, but the cases are distinguishable. The representatives in Brennan had the same substantive interests as the rest of the class, but differed from the absentees on the procedural matter of willingness to respond to discovery orders. The substance/ procedure dichotomy is a shaky one, but in this case it suffices to show that the representative's interests in the outcome of the case were not adverse to those of the absentees. In Four Seasons the interests of the representative in the substance of the settlement were allegedly adverse to those of the absentee Ohio. 
and a half years had elapsed between the dismissal of movants' claims and the filing of their rule 60 (b) motion. ${ }^{146}$

The Brennan court expressly left open the question whether a showing of inadequate representation would have rendered the judgment void as to the absentees. The court began its inquiry by stating: " $[\mathrm{I}] \mathrm{f}$.we accept movants' contention that the district judge erroneously assumed the power to direct interrogatories to 'absent' class members, it is at least arguable that the dismissal of movants' claims is void."147 The majority did not specify whether voidness would be attributable to inadequate representation or to misuse of rule $23(\mathrm{~d})$ by the trial judge, ${ }^{148}$ but the dissenting judge based his opinion on grounds of inadequate representation. He wrote:

The judgment purporting to dismiss their claims with prejudice was predicated solely on a factor which differentiated them from the rest of the class. ... In this case movants' interest in avoiding the sanction of dismissal with prejudice ... was a matter of indifference to the representative plaintiff. ${ }^{149}$

It appears that this position is the more acceptable one. Regardless of which view was correct as to the factual adequacy or inadequacy of representation in the suit under review in Brennan, the court there seems in principle to have endorsed the constitutional necessity of adequate representation above and beyond receipt of notice.

Another recent case, Dierks $v$. Thompson, ${ }^{150}$ supports the position that only those absentees who have been adequately represented may constitutionally be bound by the class action judgment. There the court reviewed, among other things, the trial court's decision to let a suit proceed as a class action. Former employees of a corporation sued the corporation's trustees to

146450 F.2d at 1003 .

$1+17 \mathrm{Id}$.

${ }^{148}$ FED. R. Giv. P. 23(d) provides in part: "In the conduct of actions to which this rule applies, the court may make appropriate orders . . .."

Other (b)(3) cases have sustained the power of the trial judge to give such additional notice and to require that absent class members respond as a condition of recovery. See, e.g., Philadelphia Elec. Co. v. Anaconda Am. Brass Co., 43 F.R.D. 452, 459 (E.D. Pa. 1969): Harris v. Jones, 41 F.R.D. 70, 74-75 \& nn.9 \& 10 (D. Utah 1966). The position presents problems: If known absentees who receive individual notice are required to take affirmative action, they are discriminated against in relation to unknown absentees who do not receive individual notice and cannot be expected to respond to notice by publication which they may never have seen.

149450 F.2d at 1007 .

150 414 F.2d 453 (1st Cir. 1969). 
determine the employees' rights under its profit-sharing plan and trust fund. ${ }^{151}$ In considering whether the plaintiffs who brought suit were "truly representational" of all the employees, the court said:

Unless the relief sought by the particular plaintiffs who bring the suit can be thought to be what would be desired by the other members of the class, it would be inequitable to recognize plaintiffs as representative, and a violation of due process to permit them to obtain a judgment binding absent plaintiffs. ${ }^{152}$

Although the court concluded that the representatives might have represented only one of two groups of employees with conflicting interests, it held that due process had been satisfied because the defendants in the suit had

actively supported the position of this [hypothetical] second group of former employees. Therefore, while it is not true that plaintiffs, as they would claim, represent all Amerotron employees, it is true that any whom they do not represent are represented by the defendants. Accordingly, we find the requirements of due process to be satisfied. ${ }^{153}$

The court employed this novel reasoning to avoid the question whether "the court may describe [in its judgment] a class that is limited to those who like the relief sought, after the others have had an opportunity to opt out."154 In other words, can a court redefine the class to be described in the judgment to include only those whose interests have been adequately represented by the named party? If it can, then a reviewing court could also redefine the "class" to be included in the judgment upon a showing that some members of the original "class" had discovered that their interests were adverse to the representative's. The absentees' interests would have to be fundamentally different from those of the representative; mere differences

151 The reviewing court's opinion suggests that the suit was a (b)(3) action by its mention of opting out and notice, id. at 456-57 \& $\mathrm{n} .7$, but nowhere is the subdivision mentioned and the suit seems to fit more easily under $(b)(1)(B)$, since interpretation of the corporation's plan "would as a practical matter be dispositive of the interests of the other members not parties to the adjudications ... ." FED. R. Civ. P. 23(b)(1)(B).

152414 F.2d at 456.

${ }^{153}$ Id. at 457.

154 Id. at 456-57. This proposition will be considered here without reference to the facts of Dierks, as it is not clear that Dierks was brought under subdivision (b)(3). Note 151 supra. 
in opinion as to how the claims were litigated or whether they should have been litigated at all ${ }^{155}$ would not warrant relief.

Under the second Dierks proposition-that a court may redefine the class to be bound by the judgment to include only those in fact adequately represented during the litigation-a reviewing court might conclude not only that some absentees had been denied adequate representation, but that they had not been bona fide members of the class represented by the named party. This analysis would make more sense than the glib resolution of the problem embodied in the first proposition in Dierks, for it is not clear, as a matter of constitutional law, that the Dierks absentees would have been accorded due process by the defendanttrustees' having argued for the absentees' position. The Dierks court was not faced with an attack on the judgment by absentees; if it had been, it probably would not have reached the conclusion that due process was satisfied. The notion that absent members of a plaintiff class can be represented by defendants is jarring and illogical. The absentees could have argued for a third possible interpretation of the contract in question. Even if the defendant trustees had supported the exact position of the absentees, they might have done so with less vigor than a representative of the absentees would have employed, especially if the trustees were supporting the second interpretation only to create a case or controversy so that the court would hear the suit.

Finally, the Dierks scheme of permitting defendants to "represent" absentees cannot be justified in light of Hansberry, in which both sides of the issue were also presented to the court. The requirement of adequate representation as embodied in amended rule 23 is based on the principle that the representation of persons, not positions, is what matters in a class suit. ${ }^{156}$ The second proposition in Dierks is the better view, because it follows the conjunction of criteria required by Hansberry and elaborated upon in Part II of this Comment, that due process is satisfied only when representatives and absentees are members of the same class and when the former adequately represent the interests of the latter. ${ }^{157}$

${ }^{155}$ See generally Leisner $x$. New York Tel. Co., 358 F. Supp. 359, 372 (S.D.N.Y. 1973).

${ }^{156}$ See text accompanying note 12 supra.

157 The Dierks theory is supported by language in an older representative action declaring that absentees who were not adequately represented could not be considered members of the class that the named party purported to represent. In Weeks $v$. Bareco Oil Co., 125 F.2d 84 (7th Cir. 1941), a spurious class action under original rule 23, the Court of Appeals for the Seventh Circuit interpreted Hansberry as having involsed two distinct classes. The court justified allowing such a suit to proceed, even though the 


\section{The Right of Absentees to Appeal}

A related issue in recent class action litigation is the question whether absentees who have not appeared, objected to representation, or intervened as parties of record may appeal from an order approving the terms of a settlement. ${ }^{158}$ The courts have not agreed on an answer, but their decisions may be relevant to the propriety of granting relief from judgment on the basis of inadequate representation.

The Court of Appeals for the Seventh Circuit refused to let absentees take an appeal for the defendant class in Research Corp. $v$. Asgrow Seed Co. ${ }^{159}$ a patent infringement class action maintained under (b)(1) and (b)(2) and an antitrust action maintained under (b)(3). The court held that an absentee who has received notice of a settlement hearing must take certain "minimal steps" in response to the notice, to preserve his right to appeal for the class. Only if "a class member intervenes or even appears in response to a notice pursuant to [rule] 23(e) and objects to the dismissal or compromise, ... . [does he have] a right to appeal from an adverse final judgment." 160 The court explained that the purpose of this seemingly harsh requirement is "to encourage or even to permit settlement" of class actions. ${ }^{161}$

In Ace Heating E Plumbing Co. v. Crane Co., ${ }^{162}$ the Third Circuit reached a conclusion contrary to that of the Seventh Circuit, holding that aggrieved absentees in a (b)(3) action can appeal from a settlement order, even when they had learned the terms of the proposed settlement before the deadline for opting out had passed. The court did not consider receipt of notice to have deprived absentees of the right to appeal:

interest of some members conflicted with that of the class for whom suit was brought, because

those with conflicting interests are not bound by the judgment in the class action. This is on the theory that they are not members of the class. The class suit, although binding on all members for whom the suitors may speak, is not binding on those whose interests are at variance with the position taken by the true members of the class.

In other words, under the Hansberry opinion, the doctrine of res judicata does not bind those who assert a position adverse to that stated by those who bring the class suit.

It. at 91 (dictum).

${ }^{158}$ All absentees have the right to appeal litigated final orders of the district court, even those who could have excluded themselves from the class during trial. Ace Heating \& Plumbing Co. v. Crane Co., 453 F.2d 30, 32 (3d Cir. 1971).

159425 F.2d 1059 (7th Cir. 1970).

${ }^{160}$ Id. at 1060; see 3B J. MoORE, supra note 24, ๆ 23.80[5], at 1557.

161425 F.2d at 1060.

162453 F.2d 30 (3d Cir. 1971). 
In such a case there may be less need to police settlements, since the question of fairness is left to the informed choice of the class members. Nevertheless, . . . [i]t is possible that, within a class, a group of small claimants might be unfavorably treated by the terms of a proposed settlement. For them, the option to join is in reality no option at all. . . . So, without court approval and a subsequent right to ask for review, such claimants would be faced with equally unpalatable alternatives - accept either nothing at all or a possibly unfair settlement. ${ }^{163}$

The court noted rule 23's recognition that "many small claimants frequently have no litigable claim unless aggregated" and that small claimants could be treated unfairly in a settlement, contrary to the rule's command that representation be fair and adequate. ${ }^{164}$

The situation posited in Ace Heating is not uncommon in the class action field. Its holding lends support to the thesis that inadequate representation, even after receipt of notice of the suit and perhaps of the very terms of a settlement, warrants some form of relief for absentees. Yet one might infer from Research Corp. that an absentee who makes no objections to the representation and who fails to appear at settlement hearings should be barred from obtaining relief from judgment.

It might be fair to require a (b)(3) absentee to object to a proposed settlement to preserve his right to appeal, but such a requirement should not necessarily apply to an absentee seeking relief from judgment. The right to be relieved from a judgment on due process grounds is more fundamental than the right to appeal a settlement order, especially if the appeal would be taken for the whole class or might adversely affect the interests of other members, who acquiesced in the original settlement. The absentee requesting relief from judgment seeks not to impose his terms upon the class and upon the opposing party, but rather to be relieved of the judgment altogether. And relief from judgment will only be granted if the absentee can prove that he was denied due process. ${ }^{165}$ In such a case there should be

${ }^{163} I d$. at 33 (emphasis supplied).

${ }^{164} \mathrm{Id}$. The result and reasoning in Ace Heating were applauded in Note, Antitrust -Federal Procedure-Attomey's' Fees and Right to Appeal, 47 TUL. L. Rev. 193, 195-96 (1972).

${ }^{165}$ See text accompanying note 114 supra. It may be that requiring an absentee to make his objections before judgment serves as a screening device by demanding of potential appellants a minimum level of interest and participation in the litigation. This 
no requirement that he monitor the proceedings in order to appear at settlement hearings or to exercise his right to opt out, unless he has been apprised of the actual settlement terms. Only then would the interest in finality dictate that appeal or relief from judgment be denied.

\section{An Absentee's Duty to Monitor the Litigation}

The most cogent and well-reasoned approach to this whole area was formulated in Gonzales $v$. Cassidy, ${ }^{166}$ a (b)(2) case in which absentees were relieved from a judgment upon proof that the named plaintiff in the earlier action had not represented them adequately. The reviewing court formulated a "twopronged inquiry" to decide whether absentees had been denied due process:

(1) Did the trial court in the first suit correctly determine initially, that the representative would adequately represent the class? and (2) Does it appear, after the termination of the suit, that the class representative adequately protected the interest of the class? ${ }^{167}$

In the first stage of the inquiry, the court asked whether the trial court erred in its initial decision to allow the suit to proceed as a class action. In the second stage the court reviewed the entire course of the proceedings, with the benefit of hindsight. Neither the trial court nor the absentees, at the time the initial determination was made, could have known all that the reviewing court knew when it conducted the second inquiry.

The representative plaintiff in Gaytan 0 . Cassidy, ${ }^{168}$ the suit from whose judgment the Gonzales plaintiffs sought relief, obtained retroactive injunctive relief for himself but only prospective relief for the other members of the class. Having received full relief for himself, he failed to appeal for the rest of the class. The trial court had determined at the outset of the suit that Gaytan would be able to represent the class fairly and adequately. ${ }^{169}$ The reviewing court concluded that because of his

screening should not be necessary for petitioners for relief from allegedly roid judgments.

${ }^{166} 474$ F.2d 67 (5th Cir. 1973).

167 Id. at 72.

168317 F. Supp. 46 (W.D. Tex. 1970), vacated, 403 U.S. 902 (1971).

169 "Gaytan was typical of the class within the meaning of Rule 23(a)(3) because he did not have interests which conflicted with those of the class, and because his claims for relief were based on the same legal or remedial theory as the appellants in the case at bar." 474 F.2d at 71 n.7. 
failure to appeal for the rest of the class, Gaytan had not fairly and adequately represented the class throughout the course of the suit. In effect, his claims and interests became atypical when he was granted relief that was denied to the rest of the class. The reviewing court's negative answer in the second stage of its inquiry resulted in granting relief from judgment: "Due process of law would be violated for the judgment in a class suit to be res judicata to the absent members of a class unless the court applying res judicata can conclude that the class was adequately represented in the first suit." 170

The Gonzales approach should not be limited to actions in which the absentees had no opportunity to exclude themselves. The theory of the amended rule-that courts must carefully scrutinize representation because of the broader res judicata effect accorded to class actions-is most relevant to (b)(3) actions, which have always been considered least amenable to broad binding effect. Absentees in a (b)(3) action lack the benefit of hindsight, mentioned above, as sorely as does the trial court. In Gonzales the change in the representative's ability to represent the class came about suddenly when he alone was granted retroactive relief; it was easily discerned by the reviewing court and thus seems an extreme case. But many other less obvious developments during the course of litigation may impair the ability of the class representative to protect the interests of absentees, and absentees who have not excluded themselves should not be bound if it develops, as it did in Gonzales, that their interests were ignored.

The considerations and circumstances in Gonzales do not differ appreciably from those that would obtain in a (b)(3) action. Brennan comes immediately to mind. The representative there sought the same relief as the other members of the class, so, initially, his claims were typical of, and not adverse to, theirs. During discovery, however, his interests diverged from theirs, enabling him to recover while the others could not, thus arguably constituting inadequate representation. The opposing party in Gonzales, seeking to bind absentees by the first judgment, advanced an "estoppel-type argument" similar to the argument that notice estops the (b)(3) absentee from claiming he was inadequately represented. Rather than arguing that the absentee should have opted out, the opposing party in Gonzales said that "since counsel for Gonzales was aware that ... the Gaytan court denied retroactive relief ...., Gonzales is estopped to attack the

${ }^{170}$ Id. at 74 
judgment collaterally because he should have intervened in Gaytan for the purposes of appeal."171 In rejecting this contention, the Gonzales court struck the proper balance between protecting absentees and requiring them to take affirmative action to protect themselves. As the court pointed out, the "purpose of Rule 23 would be subverted by requiring a class member who learns of a pending suit involving a class of which he is a part to monitor that litigation to make certain that his interests are being protected; this is not his responsibility . . .."172

An argument can be made that requesting exclusion is the responsibility of the (b)(3) absentee, but such an argument overestimates the ability of the absentee to make an informed judgment about opting out and overemphasizes the sanctions attendant upon failure to do so. ${ }^{173}$ If a reviewing court can grant absentees relief from judgment in a (b)(1) or (b)(2) action (in which the Federal Rules themselves deem the absentees to be situated similarly to the representative) where the trial court's initial adequate representation determination was correct, because the court finds after judgment that the representation turned out to be inadequate, it would be wrong to bind a (b)(3) absentee who makes a faulty judgment, or an informed judgment that becomes irrelevant due to later developments, not to opt out.

\section{Conclusion}

From the deceptively plain framework of rule 23, a substantial body of law has arisen on the interaction of notice and adequate representation. Cases dealing with due process requirements for representative suits range from the simple to the complex, factually and conceptually. Assuming throughout the situation of an inadequately represented absentee, one can imagine numerous variations on the theme, each requiring its own resolution of the competing interests. At one extreme is the simple case of the (b)(1) or (b)(2) absentee, who never had a chance to remove himself from the class. At the other extreme in factual complexity but analytically almost as clear-cut is the case of the (b)(3) absentee who could have requested exclusion, who knew

${ }^{171}$ Id. at 76. Note that the court did not speak to the question whether Gonzales could have appealed for the class without having taken some form of action. One of two conclusions may be drawn: either (1) the court would have allowed an appeal as willingly as it granted relief from judgment, or (2) the court would not have allowed an appeal but considered relief from judgment on due process grounds fundamentally different.

${ }^{172} I d$.

${ }^{173}$ See generally text accompanying notes $89-97$ \& 103 supra. 
the exact terms of a settlement order, and who was not forced by circumstances to remain in the class. Relief from judgment would be warranted in the first case and unacceptable in the second.

In the intermediate cases, courts will arrive at fair results "[o]nly by sifting facts and weighing circumstances." ${ }^{74}$ In most cases of the (b)(3) variety, the absentee who can prove inadequate representation should be relieved from the effect of a judgment, regardless of his having received notice. This Comment began with the question whether such an absentee, with notice of the suit and nothing more, can successfully attack a judgment that purports to bind him. The courts have implied that he can, and reason suggests that he should be able to do so. More difficult questions arise as the absentee's opportunity to participate is expanded. A (b)(3) absentee may have received more than mere notice of the suit. He may have been notified of settlement hearings under 23(e) and perhaps of the terms of the settlement agreement, notices effectively inviting him to take part in the suit. He may have been required to respond to discovery orders as a condition of recovery, or to intervene of record to preserve his right to appeal. Any of these novel or supplemental procedures, if adopted by a trial court, transform the nature of the class action by demanding more participation by absentees.

As the representative is divested of his almost exclusive control of the litigation, the suit becomes less a representative suit. Whether this is desirable or undesirable is an issue unto itself, but the trend away from exclusive control by the representative harbors implications for the adequate representation requirement. The Constitution demands that representation be fair and adequate if a person not before the court is to be bound by a judgment. The standards for adequacy should not be lowered when courts require absentees to assist in the conduct of a suit through discovery, settlement hearings, or the like. Absentees should not have to monitor the course of litigation, even if they do have to respond to orders of the court.

Litigating the case is the business of the representative party. Although each absentee should be offered the opportunity to enter an appearance or to request exclusion, those who choose neither course should be guaranteed the next best alter-

${ }^{174}$ Burton $x$. Wilmington Parking Authority, 365 U.S. 715, 722 (1961). 
native to a day in court. In the class action context, that alternative is fair and adequate representation by the party who is before the court. Accepting anything less would violate the rule; interpreting the rule to require less would violate the Constitution. 
. 


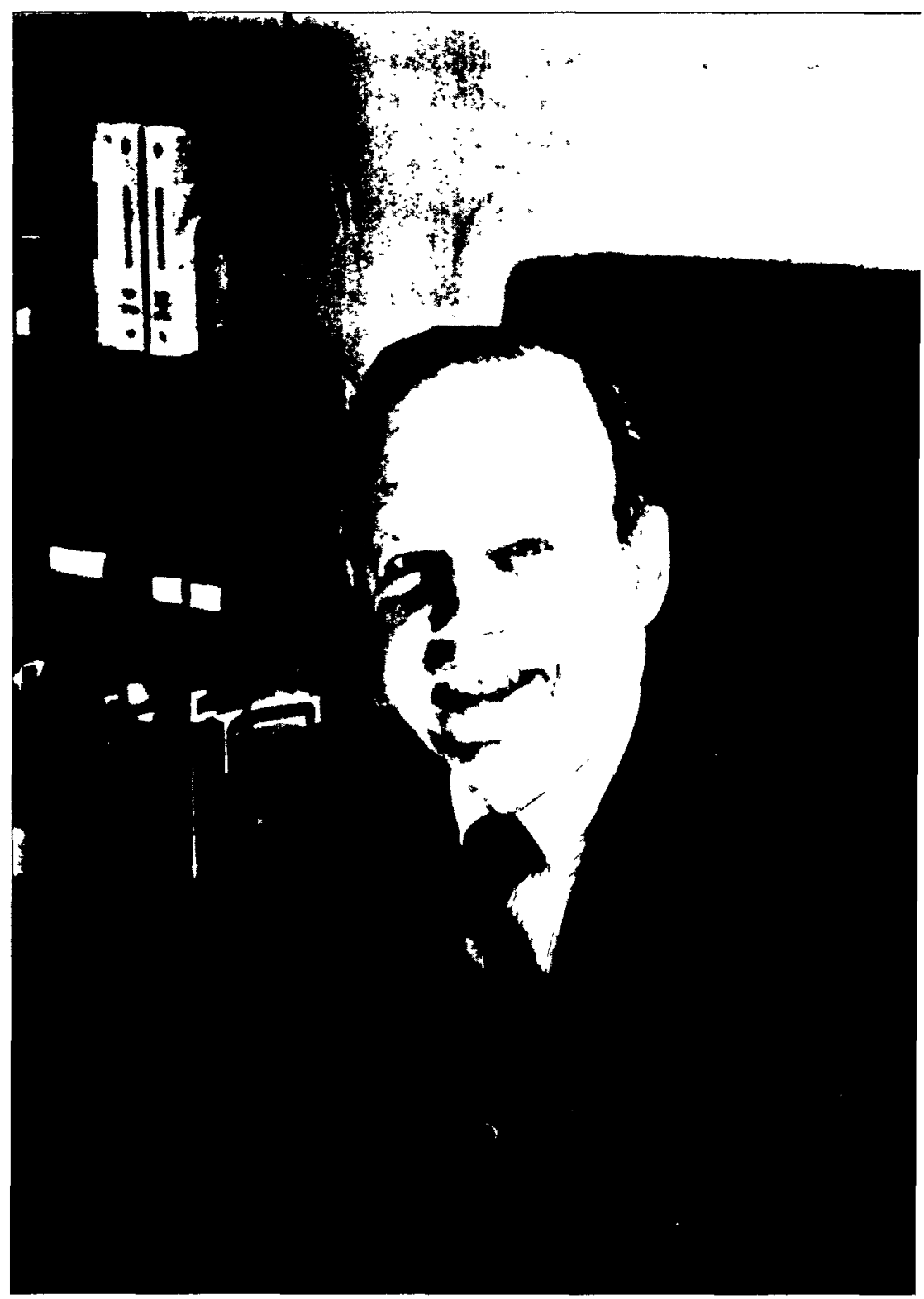

The Editors dedicate this issue of the Law Review to

BERNARD WOLFMAN

upon his retirement as Dean of the Law School 
